\title{
Rapid Development of Microbial Strains for Bioremediation of Military Soils and Dredged Materials Contaminated with Polycyclic Aromatic Hydrocarbons
}

by Douglas Gunnison, Mark E. Zappi Environmental Laboratory

John R. Marcev AScl Corporation 
The contents of this report are not to be used for advertising, publication, or promotional purposes. Citation of trade names does not constitute an official endorsement or approval of the use of such commercial products.

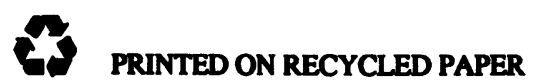




\section{Rapid Development of Microbial Strains for Bioremediation of Military Soils and Dredged Materials Contaminated with Polycyclic Aromatic Hydrocarbons}

by Douglas Gunnison, Mark E. Zappi

Environmental Laboratory

U.S. Army Corps of Engineers

Waterways Experiment Station

3909 Halls Ferry Road

Vicksburg, MS 39180-6199

John R. Marcev

AScl Corporation

East Clay Street

Vicksburg, MS 39180

Final report

Approved for public release; distribution is unlimited

Prepared for Discretionary Research Program

U.S. Army Engineer Waterways Experiment Station

3909 Halls Ferry Road, Vicksburg, MS 39180-6199 


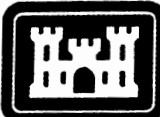

US Army Corps of Engineers

Waterways Experiment Station

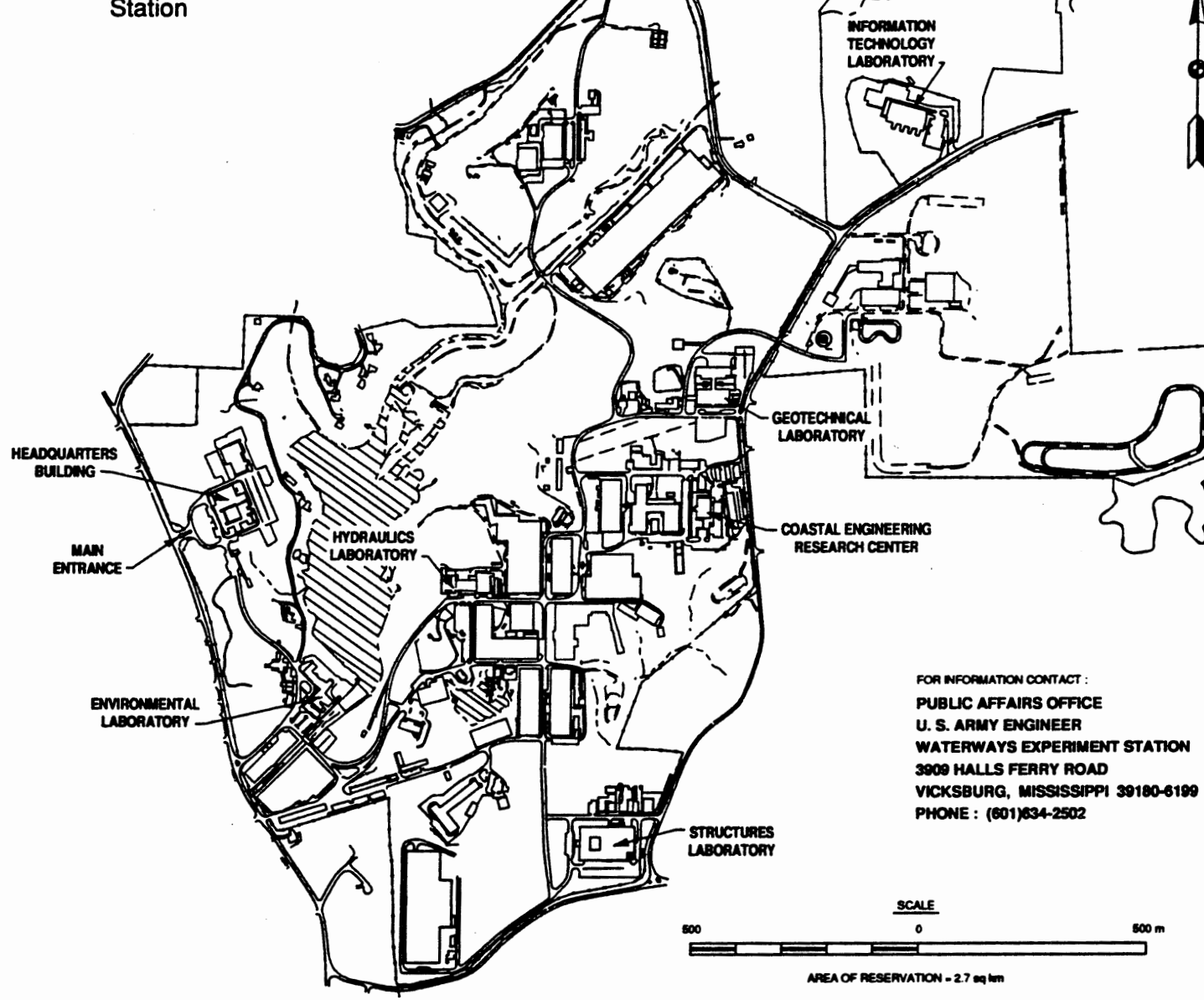

\section{Waterways Experiment Station Cataloging-in-Publication Data}

Gunnison, Douglas.

Rapid development of microbial strains for bioremediation of military soils and dredged materials contaminated with polycyclic aromatic hydrocarbons / by Douglas Gunnison, Mark E. Zappi, John R. Marcev ; prepared for Discretionary Research Program, U.S. Army Engineer Waterways Experiment Station.

53 p. : ill. ; $28 \mathrm{~cm}$. - (Technical report ; EL-93-18) Includes bibliographical references.

1. Polycyclic aromatic hydrocarbons - Biodegradation. 2. In situ bioremediation. 3. Dredging spoil - Environmental aspects. 4. Soil pollution. I. Zappi, Mark E. II. Marcev, John. III. U.S. Army Engineer Waterways Experiment Station. IV. Discretionary Research Program (U.S. Army Engineer Waterways Experiment Station) V. Title. VI. Series: Technical report (U.S. Army Engineer Waterways Experiment Station) ; EL-93-18.

TA7 W34 no.EL-93-18 


\section{Contents}

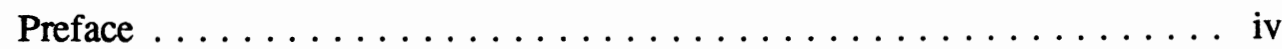

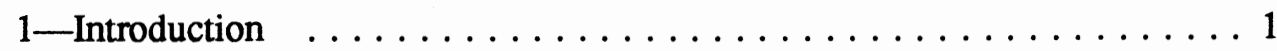

Background and Relevance $\ldots \ldots \ldots \ldots \ldots \ldots \ldots \ldots \ldots \ldots$

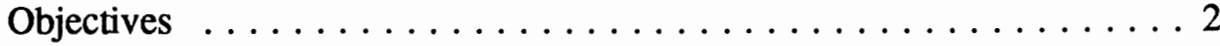

2-Literature Review $\ldots \ldots \ldots \ldots \ldots \ldots \ldots \ldots \ldots \ldots \ldots \ldots \ldots \ldots$

Environmental Concerns $\ldots \ldots \ldots \ldots \ldots \ldots \ldots \ldots \ldots \ldots$

Microbial Degradation of PAHs $\ldots \ldots \ldots \ldots \ldots \ldots \ldots \ldots$

Degradation of PAHs in Mixed Culture, Soils, Sediments, and

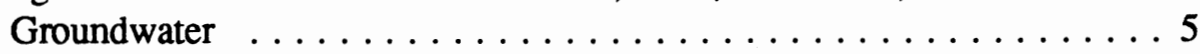

Biotreatment Processes $\ldots \ldots \ldots \ldots \ldots \ldots \ldots \ldots \ldots$

3-Rationale for the Research Approach $\ldots \ldots \ldots \ldots \ldots \ldots \ldots$. 8

4-Methods and Materials ..................... 10

Soil Collection and Analysis . .................. 10

Isolation of PAH-Degrading Microorganisms $\ldots \ldots \ldots \ldots \ldots \ldots 10$

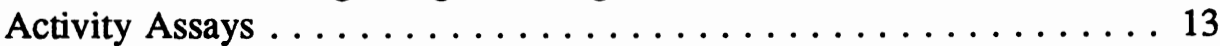

Analytical Chemistry ..................... 15

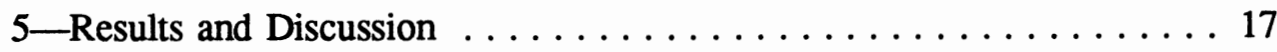

Isolation of PAH-Degrading Microorganisms from Ninth

Avenue Soil ........................... 17

Enrichment and Screening Tests on Jennison-Wright Soils . . . . . . 17

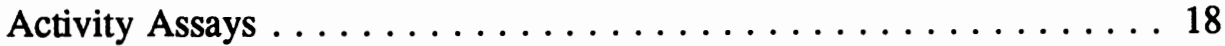

6 -Conclusions ........................... 22

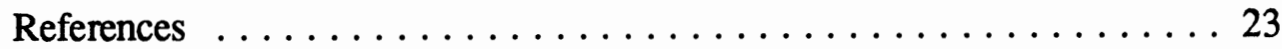

Figures 1-6

Tables 1-8

Appendix A: Screening of Jennison-Wright Soil for Degradation of

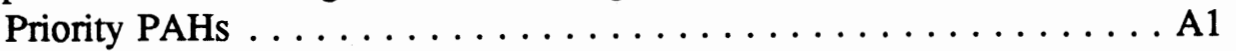

SF 298 


\section{Preface}

The study reported herein was conducted by the Environmental Laboratory (EL) of the U.S. Army Engineer Waterways Experiment Station (WES), Vicksburg, MS. The research was sponsored by the WES Laboratory Discretionary Research and Development Plan (Lab Demo) for fiscal years 1991, 1992, and 1993.

The study was conducted by Dr. Douglas Gunnison of the Ecosystem Processes and Effects Branch (EPEB), Ecosystem Processes and Effects Division (EPED), EL; Mr. Mark E. Zappi of the Environmental Restoration Branch, Environmental Engineering Division (EED), EL; and Mr. John R. Marcev of the American Scientific International Corporation (AScI). Technical assistance was provided by Ms. Patricia Reilly, Ms. Jane M. Brazil, and Mr. Michael Gates, AScI. Analytical chemistry assistance was provided by Ms. Ann Strong, Mr. Richard Karn, and Mr. Robert Jones of the Environmental Chemistry Branch, EED, EL. Drs. Judith C. Pennington, James M. Brannon, and William M. Davis of the EPEB provided technical reviews.

The study was conducted under the direct supervision of Dr. Richard E. Price, Acting Chief of the EPEB, and under the general supervision of Mr. Donald L. Robey, Chief, EPED, and Dr. John Harrison, Director, EL.

Dr. Robert W. Whalin was Director of WES. Commander was COL Bruce K. Howard, EN.

This report should be cited as follows:

Gunnison, D., Zappi, M. E., and Marcev, J. R. (1993). "Rapid development of microbial strains for bioremediation of military soils and dredged materials contaminated with polycyclic aromatic hydrocarbons," Technical Report EL-93-18, U.S. Army Engineer Waterways Experiment Station, Vicksburg, MS. 


\section{Introduction}

\section{Background and Relevance}

Polycyclic aromatic hydrocarbon (PAH) compounds are nonpolar hydrophobic molecules having two or more fused benzene rings and aqueous solubilities of approximately $32 \mathrm{mg} / \ell$ (naphthalene) to less than $0.001 \mathrm{mg} / \ell$ (perylene) (Laha and Luthy 1991). PAHs are components of petroleum-based fuels and are also produced by combustion of fossil fuels and other organic matter. Thus, many soil and groundwater environments in the vicinity of coal-fired plants and conversion facilities, petroleum plants, waste disposal sites, and fuel spills are contaminated with PAHs. Dredged materials from harbors in industrial areas also often contain high levels of these compounds. Many PAH compounds are toxic, carcinogenic, and resistant to biodegradation. For this reason, rapid removal of PAHs from environmental systems is important.

One of the most effective bioremediation strategies for soils and sediments containing PAHs is the periodic manipulation and fertilization of the contaminated material under aerobic conditions (land farming). However, degradation with this practice is slow and generates potentially harmful leachates. In addition, land disposal of waste materials has been forbidden by the Hazardous and Solid Waste Disposal Act (HASWA) of 1984. This legislation essentially prohibits land disposal of most waste without prior treatment to achieve established standards. Thus, land farming may not be feasible for severe cases of soil or sediment pollution. As a result, PAH-contaminated soils from military installations and PAH-contaminated dredged materials from U.S. Army Corps of Engineers (CE) Civil Works activities may require treatment under confined conditions such as soil/sediment washing in a lined facility or in bioslurry reactors. These treatment systems have limited soil capacities. Treatment should be accelerated so that retention times for individual soil loads are as short as possible. In confined treatment systems, water, nutrients, cosubstrates, and/or surfactants can be added to the soil to stimulate biodegradation by the native soil microflora. However, prolonged incubation is often required to obtain large populations of effective microorganisms. Addition of non-native microbial isolates having vigorous degradational activities may sometimes be effective. However, the treatment environment is often hostile to these added microorganisms. 
Rapid isolation and characterization of individual microbial strains or interactive groups of microorganisms (consortia) effective in PAH degradation from the contaminated soil are highly desirable. Such microorganisms can be produced in large quantities and returned to the same soil as part of a treatment process. These isolates should be adapted to the environmental conditions present, since they are native to the soil undergoing biotreatment. The feasibility of this approach in bioslurry treatment and treatment of soils in lined oxidation or soil washing facilities has not been previously examined.

\section{Objectives}

The study had the following objectives: (a) to develop a technology to rapidly obtain native microorganisms or consrotia with the ability to degrade PAH compounds in soils and sediments subject to aerobic biological treatment; (b) to select those microorganisms able to degrade both a broad spectrum of PAH compounds and those PAH compounds normally resistant to biological treatment (pyrene, for example); and (c) to verify the technology for soils containing high levels of PAHs. 


\section{Literature Review}

\section{Environmental Concerns}

Public pressure for pollution attenuation and environmental restoration has increased rapidly in recent years. The magnitude of the contamination problem is enormous. Hoffmann (1982) estimated that more than 70,000 commercial chemicals are used in the United States and approximately 3,000 new compounds are added each year. Manufacturing, transportation, and disposal activities offer many opportunities for release of these materials into the environment where they may be combined with contaminants from a variety of other sources (Hites, Laflamme, and Farrington 1977). Substantial volumes of hazardous wastes have been reduced through available technologies; however, up to an estimated 90 percent of hazardous wastes continue to be handled with unsound practices (U.S. Environmental Protection Agency (USEPA) 1978). Excluding the costs for pollution abatement and waste reduction at private and public facilities, the costs for remediation of currently known "high priority" hazardous waste sites have been estimated at approximately 1 billion dollars (Catallo, Therberge, and Bender 1989, cited in Catallo and Portier 1992). However, numerous other valid priorities compete for available monies. Therefore, funds required for extensive cleanups are likely to be available for only a few of the highest priority sites. A great need exists for development of remediation technologies that are both effective and economical.

The PAHs are one of the categories of contaminants that is amenable to biotreatment. PAHs are a minor component of gasoline, but are important constituents of the medium distillates (diesel and fuel oils, kerosene, jet fuel) (Song, Wang, and Bartha 1990). Therefore, PAHs occur in spills in soils and sediments around storage tanks, both above and below ground, and in petroleum refinery soils. PAHs are also found in emissions from automobile exhausts and power production, in soils from gas manufacturing plants (Erickson, Loehr, and Neuhauser 1993), and as contaminants in sediments in industrial areas that have received industrial and power plant runoff (Herbes 1977). PAHs also occur as major components (85 percent) of creosote used in preservation of wood (Mueller, Chapman, and Pritchard 1989; Mueller et al. 1991a). As a result soils in areas where creosote treatment has been carried out are also contaminated. Several PAHs are toxic (Swartz et al. 1990, Tagatz et al. 1983), teratogenic (Mueller et al. 1991b), and mutagenic or carcinogenic 
(McCann et al. 1975, McCann and Ames 1976, Rinkus and Legator 1979, Fabacher et al. 1988). In addition, PAHs are often persistent, with many of the multiringed structures being particularly refractory to microbial attack (Cerniglia 1984). Consequently, the presence of these compounds in air, water, and sediment is undesirable (Epstein 1983).

\section{Microbial Degradation of PAHs}

\section{Aerobic pathways}

Cerniglia (1984), Gibson and Subramanian (1984), and Edwards (1983), and Bossert and Bartha (1986) have summarized the results of recent investigations of aromatic hydrocarbon degradation, including the PAHs. Some of the low molecular weight PAHs are able to undergo evaporation and microbial degradation from the dissolved state. Aerobic biological removal of the PAHs may sometimes occur readily because many of them occur naturally, perhaps even forming important structural units of humic substances (Martin, Haider, and Bondietti 1972).

Many bacteria (Bogardt and Hemmingsen 1992; Boldrin, Tiehm, and Fritzsche 1993; Sanseverino et al. 1993), fungi (Field et al. 1992, Pothuluri et al. 1992), algae (Narro et al. 1992a,b), and yeasts (MacGillvray and Shiaris 1993) are capable of degrading PAHs. However, the hydroxylation mechanisms among these groups of organisms are fundamentally different (Cerniglia 1984). In addition, most studies of microbial metabolism of PAHs have been conducted with pure cultures and/or purified enzymes. This work provides an understanding of the ability of microorganisms to degrade these compounds and the mechanisms involved in degradation. However, little has been done to evaluate the conditions required for biodegradation in the natural environment.

At the time Cerniglia's (1984) article was written, the pathways that had been established were predominantly aerobic. According to Cerniglia (1984) and Gibson and Subramanian (1984), many pathways for aerobic degradation of complex PAHs require participation by several organisms, although exceptions do exist. For example, Heitkamp, Franklin, and Cerniglia (1988) isolated a Mycobacterium able to mineralize pyrene. Bacteria oxygenate compounds using mono- or dioxygenases to form dihydrodiols having a cis-configuration, while fungi use a monooxygenase to form transhydrodiols. Methanotrophicmixed bacterial cultures able to degrade trichloroethylene apparently also attack naphthalene using a methane monooxygenase (Henrysson and McCarty 1993).

Field et al. (1992) observed that several strains of lignolytic white rot fungi are able to significantly reduce anthracene to low levels. Many of these are also able to remove benzo[a]pyrene. Approximately half of these strains convert large quantities of anthracene to anthraquinone, a dead-end metabolite. Other investigators have observed that the white rot fungus Phanerochaete 
chrysosporium produces quinones from several different PAHs (Haemmerli et al. 1986; Hammel, Kalyanaraman, and Kirk 1986). By contrast, Field et al. (1992) found that other strains removed anthracene without accumulation of the quinone, while none of the strains tested accumulated PAH quinones during benzo[a]pyrene degradation. The production of the quinones, and presumably also some of the degradational activity, is associated with extracellular substances produced by the fungi. Other investigators have also observed the general ability of lignolytic fungi to attack PAHs (Aust 1990, Bumpus et al. 1985), including fluorene and benzo[a]pyrene (George and Neufeld 1989, Qui and McFarland 1991). Particular reference has been made to the ability of Phanerochaete chrysosporium to degrade radiolabeled PAHs (Bumpus 1989, Bumpus et al. 1985). The highest level of ${ }^{14} \mathrm{CO}_{2}$ known to be released by this organism is only 19 percent, although much greater concentrations are often measured as unidentified intermediates in aqueous and organic extract phases (Bumpus 1989; Hammel, Green, and Gai 1991).

\section{Anaerobic pathways}

Recent research has suggested that monocyclic and polycyclic aromatic hydrocarbons can also be transformed by anaerobic microbial communities under denitrifying, fermentative (including methanogenic), and, in some cases, sulfate-reducing conditions (Grbic-Galic et al. 1990). However, very little research has documented the importance of anaerobic degradation of these compounds (Grbic-Galic and Young 1985, Grbic-Galic 1989, Grbic-Galic et al. 1990). Mihelcic and Luthy (1988a,b) reported nitrate-supported degradation of acenaphthene and naphthalene from levels of 1 and 3 to $4 \mathrm{mg} / \ell$, respectively, to below detection $\left(5.0 \times 10^{-3} \mathrm{mg} / \mathrm{l}\right)$ in less than 9 weeks.

\section{Degradation of PAHs in Mixed Culture, Soils, Sediments, and Groundwater}

While PAHs having two to four aromatic rings are readily biodegraded (Stroo 1992), PAH compounds having more than four rings are degraded much more slowly (Heitkamp, Franklin, and Cerniglia 1988). High molecular weight PAHs having five or more rings resist bacterial degradation in soils and sediments (Bossert and Bartha 1984, Bossert and Bartha 1986, Heitkamp and Cerniglia 1987, 1989). Weathered PAHs in soils that have had the opportunity to lose readily degradable PAHs appear to almost completely resist biodegradation (Erickson, Loehr, and Neuhauser 1993). The high molecular weight PAHs that comprise 85 percent of the materials in coal-tar creosote and pentachlorophenol in creosote resist microbial attack and persist in contaminated environments such as soils and sediments (Bossert, Kachel, and Bartha 1984; Bossert and Bartha 1986; Mueller, Chapman, and Pritchard 1989; Mueller et al. 1991a). 
While many authors suggest that molecular structure is responsible for the inability of soil microorganisms to degrade some PAHs, others indicate that recalcitrance of the higher molecular weight PAHs may be due to insolubility and strong sorption to soils (Means et al. 1980; Volkering et al. 1992; Weissenfels, Klewer, and Langhoff 1992). The effect of sorption on degradation is further supported by the work of Mihelcic and Luthy $(1986,1988 \mathrm{a}, \mathrm{b})$. They suggest that degradation of PAHs depends on interrelationships between desorption kinetics and reversibility, the population of PAH-degrading microorganisms, and competition for nitrate from labile portions of the natural soil organic matter.

To overcome the low solubility, several microorganisms apparently modify hydrocarbons to yield surfactants and emulsifiers (Rosenberg et al. 1979; Zajick and Mahomedy 1984; Desai, Patel, and Desai 1988) or modify surfaces to reduce sorption (Bellin and Rao 1993). Surfactants and bioemulsifiers undoubtedly provide the formative microorganisms with the means to better obtain these insoluble carbon sources (Desai, Patel, and Desai 1988). However, contradictory behavior is sometimes observed with respect to the effect of surfactants on PAH degradation. Thus, Laha and Luthy (1991) indicated that micelles of nonionic surfactants inhibit degradation of phenanthrene by a PAHdegrading inoculum, while Guerin and Jones (1988) reported that nonionic surfactants (Tween ${ }^{\mathrm{TM}}$ compounds) enhanced degradation of phenanthrene by a species of Mycobacterium. Bellin and Rao (1993) demonstrated alteration of soil surfaces through development and/or addition of bacterial biomass. This apparently reduces sorption of quinoline and naphthalene, resulting in increased transport in soil.

Microbial degradation of individual petroleum hydrocarbons, including PAHs, and the pathways responsible for their degradation in soils are reviewed by Atlas (1981); Jones (1977); Westlake, Jobson, and Cook (1978); Dibble and Bartha (1979); Fedorak and Westlake (1981); Aamand et al. (1989); Carberry and Lee (1990); and Wilson and Jones (1993). A report on site-specific studies is given by Ridgeway et al. (1988). Soils contaminated by petroleum fuel spills are considered hazardous wastes, and the disposal of large volumes of contaminated soil by burial in secure sites or incineration is very expensive. By contrast, land treatment of oily refinery sludges has been conducted for years with generally good results (Song, Wang, and Bartha 1990).

Bossert and Bartha (1984) summarized the structure, degradability, and toxicity of hydrocarbons in soil, based on the reviews of Bartha and Atlas (1977), Atlas (1981), and the National Academy of Science (1984). According to this information, petroleum components, including the aromatic compounds in the $\mathrm{C}_{10}$ to $\mathrm{C}_{22}$ range are the least toxic and most biodegradable. As indicated, the aromatic compounds having two to three rings are completely degradable and may be used as carbon and energy sources by PAH-degrading microorganisms (Herbes and Schwall 1978, Atlas 1981). By contrast, PAH compounds having four or more condensed rings are extremely resistant to degradation, and degradation often requires active participation by several species of microorganisms (Cemiglia 1984, Gibson and Subramanian (1984). 
At least one exception is known. Degradation of pyrene, a four-ringed PAH, is brought about by a Mycobacterium sp. (Heitkamp et al. 1988). Moreover, investigation of natural populations of microorganisms has revealed that cometabolism or cooxidation of the higher molecular weight PAHs occurs in the presence of phenanthrene, anthracene, or other usable organic substrates (Herbes and Schwall 1978, Heitkamp and Cerniglia 1988, Heitkamp et al. 1988).

The initial steps of hydrocarbon degradation are either oxygen-dependent or proceed much more rapidly under aerobic conditions (Bossert and Bartha 1984). Mihelcic and Luthy (1988a,b) demonstrated anaerobic degradation of certain PAHs under denitrifying conditions in soil slurries; however, other authors have not been as successful. Ward and Brock (1978) and DeLaune, Hambrick, and Patrick (1980) indicated that anaerobic degradation of petroleum hydrocarbons is either negligible or nonexistent. For example, biodegradation at a redox potential of $-220 \mathrm{mV}$ and $\mathrm{pH} 8.0$ removes only approximately 15 percent of radiolabeled compounds in estuarine sediment; however, biodegradation reached substantially higher levels at more positive redox potentials (DeLaune, Hambrick, and Patrick 1980).

In addition to redox potential, soils, sediments, and groundwaters do not always provide the required levels and combinations of nutrients, moisture, $\mathrm{pH}$, and temperature for optimum microbial activity. For example, too much moisture can interfere with movement of oxygen into soil, inhibiting aerobic degradation (Dibble and Bartha 1979, Atlas 1981, and Bossert and Bartha 1984).

The biodegradation of all petroleum hydrocarbons, including PAHs, is regulated by several factors. These include chemical structure of the PAH; presence or absence of other PAHs or other hydrocarbons; physical state of the PAHs; concentration of the compound(s); temperature, oxygen and moisture; concentration of inorganic and organic nutrients; and $\mathrm{pH}$. For details of the role of these factors, see Gunnison (1991).

\section{Biotreatment Processes}

Investigations of the environmental fate and bioremediation of PAHs at creosote-contaminated sites have often shown that microorganisms and pathways exist for PAH degradation, but that conditions for PAH degradation are often poor and frequently difficult to improve (Wang, Yu, and Bartha 1990). Biodegradation of the PAH components of oil sludges is often less difficult because this material is less toxic than creosote. Furthermore, most PAHs in diesel oil, kerosene, fuel oil, and jet fuel have four or fewer rings. Wang, Yu, and Bartha (1990) indicated that bioremediation of diesel oil-contaminated soils produced low concentrations of objectionable PAH residues. As a result, simple bioremediation practices (liming, fertilization, tilling) increased total hydrocarbon degradation rates, nearly eliminating PAHs in 12 weeks. 


\section{Rationale for the Research Approach}

Confined mechanisms for biotreatment are attractive because of legal concerns with land treatment. Several treatment strategies have been tried with soils contaminated with PAHs alone or in combination with other hydrocarbons. These strategies include confined reactor treatment of slurries produced with the residues remaining after soil washing of creosote-contaminated soils (Mueller et al. 1991a) and use of staged bioreactors and selected microorganisms for treatment of creosote-contaminated groundwater (Mueller et al. 1993).

Stroo (1992) has summarized the types of treatments obtained by providing native microorganisms with the environmental conditions necessary to stimulate activity within the soil matrix. To date, most of these applications require use of aerobic bacteria in combination with technologies commonly employed in agronomic or waste treatment processes. For example, soil treatment is obtained by supplying fertilizers and moisture and mixing the soil to increase availability of nutrients, moisture, and oxygen to the soil microflora. These procedures are commonly applied at petroleum refinery sites under the Resource Conservation and Recovery Act (RCRA), and with creosotecontaminated sludges and soils, including some Superfund sites. Liquid-solids contact treatment relies on controlled, efficient mass transfer obtained by adequate mixing and aeration to provide rapid, effective treatment. Nutrients may also be added to stimulate microbial activity. Some liquid-solids contact reactors can be run as closed systems, allowing volatile compounds to be trapped externally or recirculating exhaust airstreams through the treatment system. Systems utilized include lined, covered lagoons, and engineered reactor systems. Water treatment systems include conventional aerobic digestors with activated sludge, sequencing batch, fluidized bed, or fixed film systems. Any of these systems may be run in continuous or batch mode and can be applied to PAH and (PCP)-contaminated groundwaters (see, for example, Mueller et al. 1991b).

In situ biotreatment may be used when PAHs become sorbed to soils, although as indicated, sorption may limit or prohibit altogether the degradation of higher molecular weight PAHs. Innovative biodegradation practices using nitrate or sulfate as alternate electron acceptors under anaerobic conditions may - provide some improvement of biotreatment. However, as a whole, PAH 
removal seems to be much more effective under aerobic conditions. Because of their limited degradation rates in natural soils, the more complex PAHs are best treated when large quantities of air and nutrients can be moved through the system, as is the case with bioventing. Use of specialty microorganisms, such as white rot fungi, which seem to be quite effective in PAH degradation, may be appropriate in certain instances. One problem commonly encountered in PAH biotreatment is that while the low molecular weight PAHs are degraded, the higher molecular weight compounds tend to accumulate (Field et al. 1992).

As Stroo (1992) indicated, cleanup criteria for contaminated soils are based on assumptions and data that are difficult to obtain and/or verify. Therefore, Stroo suggested that risk analysis (RA) procedures do not properly consider contaminant partitioning from soil or sediment into water or organisms. He also indicated that the biotreatment process reduces the "plateau," the concentration below which rate of contaminant destruction falls off markedly. As indicated, much of this "unavailability" likely results from strong sorption to the soil, making the contaminants unavailable for movement into the aqueous phase. In like manner, these contaminants are not easily degraded by microorganisms. Since RA does not differentiate between these differences, Stroo suggested that use of risk-based criteria such as the Toxicity Characteristic Leaching Procedure (TCLP) could make bioremediation a more competitive treatment option.

For soils and sediments contaminated with petroleum hydrocarbon spills, bioremediation procedures utilizing microbial degradation with $\mathrm{pH}$ control, nutrient addition, aeration, and mixing appear to be cost-effective cleanup measures (Bossert and Bartha 1984; Wang, Yu, and Bartha 1990). However, bioremediation is often very slow. Consequently, procedures that can accelerate biodegradation will enhance bioremediation. Biotechnology may eventually improve the performance of biotreatment by selective enhancement of microbial strains capable of attacking PAH compounds having more than four rings (Stroo 1992). However, this technology does not exist presently. Consequently, treatment of these compounds is most efficiently obtained by cometabolism during biodegradation of the lower molecular weight PAH compounds. To be effective, high levels of microbial populations effective in PAH destruction must be present.

The ability to improve PAH removal by use of both native and specialty strains has been demonstrated (Mueller et al. 1992, 1993). Much of the research conducted at the Waterways Experiment Station (WES) has been directed to cleanup of soils contaminated with PAHs. Identification of microorganisms effective in PAH removal and naturally present within the contaminated soil matrix is appropriate. Once identified and isolated, the effective microorganisms can be returned in large quantities to the soil during biotreatment. This will greatly accelerate biotreatment rates, with consequent increase in treatment effectiveness and decrease in retention times for soils. 


\section{Methods and Materials}

\section{Soil Collection and Analysis}

\section{Collection and preparation}

Two contaminated soils were studied. Soil contaminated with PAHs and benzene-ethylbenzene-toluene-xylene (BTEX) compounds was obtained from the Ninth Avenue Superfund site in Gary, IN. The samples were mixed in 55-gal ${ }^{1}$ drums and redispensed into 5-gal buckets for shipment to WES at ambient temperature. A second soil sample contaminated with creosote was obtained from the Jennison-Wright Superfund site in Granite City, IL. Samples were taken from several contaminated areas within the site and composited. Upon receipt at WES, all soils were stored at $4{ }^{\circ} \mathrm{C}$ until processed.

\section{Analysis}

Soils were analyzed for particle size distribution (Patrick 1958), total organic carbon (Allison 1965), and soil moisture content at $105^{\circ} \mathrm{C}$ (gravimetric).

\section{Isolation of PAH-Degrading Microorganisms}

A medium was developed to facilitate isolation of microorganisms active on any individual PAH or group of PAHs. Microorganisms were isolated on basal salts medium (BSM) (Table 1) solidified with 1.5-percent agar (BSA) and supplemented with PAHs. To enhance buffering capacity and trace nutrients, the phosphate concentration of BSA was increased, and yeast extract and a trace metals solution (enhanced basal salt medium (EBSM)) were added (Table 1). The compositions of the remaining major nutrient and dilution media used in the investigation are also shown in Table 1.

1 To convert gallons into cubic decimeters, multiply by 3.785412 . 


\section{Isolations from Ninth Avenue soll}

The initial development of procedures was conducted with Ninth Avenue soils because this soil contains PAH-degrading microorganisms (Zappi, Gunnison, and Teeter 1993). A slurry was prepared containing the equivalent of $10 \mathrm{~g}$ oven dry weight (ODW) of Ninth Avenue soil in $90 \mathrm{ml}$ of sterile phosphate buffered saline (PBS). The mixture was shaken to break up the soil, and the resulting suspension diluted by transferring a $10-\mathrm{ml}$ aliquot to a fresh dilution bottle. A dilution to $10^{-10}$ was conducted. PAH-degrading microorganisms were enumerated by spreading $0.1-\mathrm{ml}$ aliquots of each dilution of the soil suspension onto separate plates of BSA containing $0.100 \mathrm{~g}$ of either phenanthrene, pyrene, fluorene, or 2-methylnaphthalene (the priority PAHs for Ninth Avenue soil, Table 2) per liter. The most abundant PAHs in a PAHcontaminated soil were designated as the "priority" PAHs. These compounds were used as indicators to determine the ability of microbial isolates to degrade one or more of the major PAH contaminants present. To enumerate total heterotrophic microorganisms, $0.1-\mathrm{ml}$ aliquots of each of the dilutions were placed onto PTYG agar (Table 1). Plates were incubated for 7 to 14 days at room temperature. Plates containing between 30 and 300 colonies were counted to obtain estimates of the microbial population able to grow on each medium. Representative colonies, those comprising 30 percent or more of the total microbial population, were examined with the $\mathrm{BIOLOG}^{\mathrm{TM}}$ system $^{1}$ for identification of environmental isolates.

\section{Enrichment for PAH-degraders}

Enrichment media. BSA-PAH medium used in enrichment cultures containing either 0.1 or 0.01 percent of the priority PAH was prepared as follows. A minimal amount of solvent was used to dissolve all of the priority PAHs being tested for a soil. The acetone-hexane solution of mixed PAHs was added to hot BSA at pH 7.0 immediately after autoclaving to flash off the solvent. For pure cultures, the following modification was made: (a) empty culture flasks were plugged and sterilized; and (b) an individual priority PAH was dissolved in acetone, filter sterilized, and added to each flask in quantity sufficient to give a 1-mM PAH solution upon addition of sterile basal salts medium. The acetone was subsequently evaporated to dryness with sterile air, and the sterile basal salts medium was added. This procedure caused the material to plate out on the glass walls of the flasks. To ensure even dispersion of poorly soluble PAHs, the flasks were sonicated for 1 to $3 \mathrm{~min}$ in a Branson 3200 Ultrasonic Cleaner following addition of basal salts medium.

1 BIOLOG $^{\mathrm{TM}}$ is a microbial identification system using a series of biochemical tests in liquid for metabolic characterization of bacteria. The results of these tests are subsequently entered into a computer program. The program provides an identification of the organism based on a statistical comparison to an existing database for environmental isolates. The BIOLOG ${ }^{\mathrm{TM}}$ system is routinely used by many microbiologists to identify environmental isolates (see, for example, Ghiorse and Balkwill 1983). 
Enrichment procedures. Jennison-Wright soil was enriched to obtain mixtures of microorganisms using the most abundant PAHs present. The procedure of Mueller, Chapman, and Pritchard (1989) was used. Forty-nine ml of sterile BSA-PAH medium containing either 0.002 or 0.02 percent of acenaphthalene, fluoranthene, fluorene, phenanthrene, and pyrene (the priority PAHs for Jennison-Wright soil, Table 3) were placed into a sterile $125 \mathrm{ml}$ Erlenmeyer flask and plugged with a sterile foam stopper. These media were inoculated with $1.0 \mathrm{~g}$ of PAH-contaminated soil that had been passed through a 40-mesh sieve. Inoculated media were incubated for several days at room temperature on a gyrorotary shaker at 200 revolutions per minute (rpm). A $5.0-\mathrm{ml}$ aliquot of each slurry was transferred to $45 \mathrm{ml}$ of the same sterile medium and incubated at room temperature with shaking until turbid. A $1.0-\mathrm{ml}$ aliquot of the culture was transferred to $49 \mathrm{ml}$ of the same medium, except that yeast extract was omitted if used in the parent medium. This culture was incubated as described above. The culture was transferred to fresh medium an additional three times. Resulting enrichments were streaked onto BSA containing either individual PAHs or the priority PAH mixture.

\section{Screening test}

Screening media. Several media were evaluated for use in screening microbial isolates for PAH-degrading activity. BSA-PAH agar containing the PAH dissolved in the medium was used initially. To increase the opportunity for screening isolates that required trace levels of metals and organic nutrients, EBSA was used. However, a concern developed as to whether microorganisms grown on either of these media would utilize the PAH supplied. To circumvent this occurrence, PAH overlays were prepared using a modification of the procedures of Heitkamp and Cerniglia (1988) and Bogardt and Hemmingsen (1992). BSA or EBSA was poured into petri dishes and dried for 2 days at room temperature. Priority PAHs (Table 3) were each dissolved in 1:1 acetone:hexane to produce a 2-percent (weight-to-volume) solution. A 2-percent solution of mixed priority PAHs was also prepared for each soil. The concentration of each PAH in the mixture was determined by computing the sum of the weight of total priority PAHs divided by 0.02 . The surface of each agar plate was evenly coated with one of these solutions containing PAHs using a spray atomizer. To prevent exposure of laboratory personnel to PAHs and the solvents, all operations were carried out in a fume hood. Coated plates were held in the hood an additional 1 to 2 days at room temperature to permit the solvent to evaporate.

Screening procedure. Jennison-Wright soil samples were screened to assay the degradational activity of individual microorganisms or microbial mixtures towards each of the priority PAHs using the following procedure. A 10 -ml aliquot of enrichment culture or $10.0 \mathrm{~g}$ of soil sample was transferred into a dilution bottle containing $90 \mathrm{ml}$ of PBS adjusted to $\mathrm{pH} 7.0 \pm 0.1$ with $0.1 \mathrm{~N} \mathrm{HCl}$. This sample was carried to a dilution of $10^{-10}$ in sterile PBS. Dilutions of the soil and enrichment cultures were originally plated onto BSA that 
had been sprayed with a mixture of five priority PAHs until a light coating was formed. However, microorganisms growing on this medium did not form zones of clearing that were easily distinguished from the opaque layer of mixed PAHs, and individual colonies were difficult to enumerate, with or without clearing. For these reasons, soil and enrichment dilutions were plated onto BSA plates sprayed with individual PAHs. When this was done, clearing was observed in some instances, and counts were easily obtained. Therefore, $0.1-\mathrm{ml}$ aliquots of each dilution were spread on plates of the appropriate BSAPAH overlay and PTYG agar in triplicate to enumerate the number of microorganisms active on each PAH and the total number of microorganisms present, respectively. Microbial colonies surrounded by a clear zone on the PAH overlay and microbial consortia obtained by the enrichment procedure were treated as follows: (a) individual microorganisms or consortia were subcultured on BSA plates containing the appropriate PAHs until an isolated colony was obtained; (b) predominant microorganisms were identified with the $\mathrm{BIOLOG}^{\mathrm{TM}}$ procedure; (c) petri plates containing microbial isolates were surrounded by parafilm ${ }^{\mathrm{TM}}$ to prevent moisture loss during storage at $4{ }^{\circ} \mathrm{C}$.

Individual microbial isolates were screened for activity by inoculating each onto the entire suite of individual priority PAHs on BSA-PAH plates. PAHdegrading microorganisms were identified as clear circular zones surrounding colonies against a cloudy field.

\section{Activity Assays}

\section{Preparation of pure cultures}

Pure cultures of microbial cells were selected based on their ability to degrade three or more priority PAHs as individual compounds in the screening test. Cultures were prepared for gas liquid chromatography (GLC) and benchscale slurry studies. Isolates JWI46 and/or JWI17 from Jennison-Wright were inoculated onto plates of EBSA containing $1 \mathrm{~mm}$ of phenanthrene. Colonies from the EBSM were picked into $5 \mathrm{ml}$ of sterile EBSM and incubated at room temperature under static conditions until turbid. This inoculum was poured into $300 \mathrm{ml}$ of the sterile EBSM in a $500-\mathrm{ml}$ Erlenmeyer flask and incubated at room temperature on a shaker at $200 \mathrm{rpm}$ until an optical density of 0.35 absorbance units was obtained. The cells were harvested by centrifugation at $6,084 \times \mathrm{g}$ for $20 \mathrm{~min}$, resuspended in $50 \mathrm{ml}$ of sterile PBS, and stored at $4{ }^{\circ} \mathrm{C}$ until used.

\section{Determination of PAH degradation kinetics}

The rate and extent of degradation of a representative $\mathrm{PAH}$ (phenanthrene) were determined by GLC analysis of the headspace for $\mathrm{CO}_{2}$ production by the Jennison-Wright isolate JWI46. Serum bottles containing $25.0 \mathrm{ml}$ of media in three replicates were sealed with Teflon-coated silicone septa and crimped with aluminum caps. Each of the following treatments was establishing, using 
$1.0 \mathrm{ml}$ of pure culture suspended in PBS as the inoculum: (a) EBSM containing inoculum, phenanthrene, and yeast extract; (b) EBSM containing inoculum and phenanthrene without yeast extract; (c) EBSM containing inoculum and yeast extract only; (d) EBSM containing phenanthrene and yeast extract, but left uninoculated to provide a control; and (e) EBSM with inoculum, but without phenanthrene or yeast extract. These cultures were incubated on a gyrorotary shaker at $30^{\circ} \mathrm{C}$ and $100 \mathrm{rpm}$. At time 0 and at 2-day intervals for 1 week thereafter, $50 \mu \mathrm{l}$ samples were taken from the headspace of each bottle and injected into a Hewlett Packard Model 5890 Series II GLC to determine $\mathrm{CO}_{2}$ production and $\mathrm{O}_{2}$ consumption. The GLC was equipped with a Supelco Carboxen 1000 column and a thermal conductivity detector. The injector and detector were held at $230^{\circ} \mathrm{C}$. The column oven was set at $35^{\circ} \mathrm{C}$ for the first $5 \mathrm{~min}$, then brought to $225^{\circ} \mathrm{C}$ at $20^{\circ} \mathrm{C} / \mathrm{min}$. The carrier gas was helium at a flow rate of $20 \mathrm{ml} / \mathrm{min}$. Unknown sample peaks were identified by comparison with gas standard mixtures. Relative rates of oxygen consumption and carbon dioxide production were determined based on average changes in content compared with initial (time 0 ) samples.

\section{Determination of PAH mineralization}

To verify the mineralization of PAHs, Jennison-Wright isolate JWI46 was incubated with radiolabeled fluoranthene and pyrene, and Jennison-Wright isolate JWI17 was incubated with radiolabeled fluorene and phenanthrene as follows. Twenty-five $\mathrm{ml}$ of a triple-washed cell suspension of each isolate in sterile ammonium sulfate-free basal salts medium was adjusted to an optical density of 0.35 absorbance units. Each $25.0-\mathrm{ml}$ suspension was injected into a $100-\mathrm{ml}$ serum bottle, which was then equipped with a sterile $25-\mathrm{mm}$ vial used to hold a $\mathrm{CO}_{2}$-trapping solution, sealed with a serum stopper, and crimped shut. The air in each serum bottle was replaced with $\mathrm{CO}_{2}$-free air. A total of $1.9 \mathrm{ml}$ of one of the diluted stock solutions, containing approximately $10 \mu \mathrm{g}$ of phenanthrene-9-[ $\left.{ }^{14} \mathrm{C}\right]$ (sp. activity $161,728 \mathrm{DPM} / \mu \mathrm{g}$ ), fluoranthene-3- $\left[{ }^{14} \mathrm{C}\right]$ (sp. activity 598,240 DPM/ $/ \mathrm{g}$ ), fluorene-9- $\left[{ }^{14} \mathrm{C}\right]$ (sp. activity 187,966

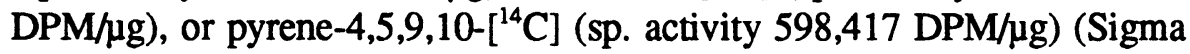
Chemical Company, St. Louis, MO) was added to each bottle. Bottles were incubated on a gyrorotary shaker for $48 \mathrm{hr}$ at $30^{\circ} \mathrm{C}$ and $100 \mathrm{rpm}$.

Qualitative degradation of ${ }^{14} \mathrm{C}$-labeled PAHs was detected by trapping and measuring released ${ }^{14} \mathrm{CO}_{2}$. Following incubation, sufficient $1 \mathrm{~N} \mathrm{HCl}$ was added to each bottle to bring the $\mathrm{pH}$ of each cell suspension to 2-3. One-hundredfifty $\mu \mathrm{l}$ of $1 \mathrm{~N} \mathrm{KOH}$ was added to each trap vial. The bottles were incubated $1 \mathrm{hr}$ with shaking, after which the $\mathrm{KOH}$ was removed from each trap and added to separate scintillation vials containing $15 \mathrm{ml}$ of Ultima Gold ${ }^{\mathrm{TM}}$ Liquid Scintillation Cocktail. Each trap vial was rinsed with an additional $150 \mu$ l of $\mathrm{KOH}$, and this was added to the same scintillation vial. To determine the amount of radiolabeled $\mathrm{CO}_{2}$ trapped, each sample was counted for 10 min on a Packard 2500 Liquid Scintillation Counter. Counts were corrected for background and quenching and converted to disintegrations per minute with the use of the external standard method. 


\section{Bloslurry activity assays}

Jennison-Wright isolate JWI46 was used to test the effectiveness of adding PAH-degrading isolates back to the soil for enhanced PAH-destruction during bioslurry treatment. ${ }^{1}$ Jennison-Wright isolate JWI46 was selected based on its ability to clear priority PAHs in the screening test and to mineralize representative PAHs in the PAH mineralization study (see results section). The culture was grown in $1,500 \mathrm{ml}$ of basal salts medium containing $1-\mathrm{mm}$ phenanthrene for 5 to 7 days at $30^{\circ} \mathrm{C}$. Cells were harvested with centrifugation at $6,084 \times \mathrm{g}$ for $20 \mathrm{~min}$ and resuspended in sterile enriched reverse osmosis water (Table 1). Densities of added cells were adjusted to provide final concentrations of $1 \times 10^{7}$ colony-forming units (CFU)/ml in the slurries.

Four replicates of Jennison-Wright soil were prepared in each of the following treatments in sterile enriched water (formulation given in Table 1): (a) gamma ray-sterilized soil with JWI46 cell suspension; (b) unsterilized soil with JWI46 cell suspension; and (c) gamma ray-sterilized soil poisoned with 0.5 -percent $\mathrm{HgCl}_{2}$. The mercury was used as added insurance against contamination during repeated sampling of the soil slurry. All slurries contained 33-percent soil with sufficient enriched reverse osmosis water to make a total volume of $250 \mathrm{ml}$.

Each flask was incubated on a gyrorotary shaker at ambient temperature and $100 \mathrm{rpm}$. At time 0 and at weekly intervals for 1 month, two flasks of each soil treatment were sampled for the following: microorganisms; percent solid, volatile, and total residues; and temperature. Microorganisms were enumerated on (a) BSA-phenanthrene containing the SL-6 trace elements solution, (b) EBSA containing phenanthrene as a spray coating, and (c) PTYG.

At the end of incubation, slurries were centrifuged at $6,084 \times \mathrm{g}$ to separate soil and water phases. Approximately $230 \mathrm{ml}$ of each soil phase and $470 \mathrm{ml}$ of each aqueous phase were sent to the analytical laboratory for analysis. Each aqueous phase was analyzed for priority PAH content. Each soil phase was analyzed for total, volatile, and fixed residues, total residual petroleum hydrocarbons (TRPHs), and priority PAHs.

\section{Analytical Chemistry}

PAHs were determined following elution from a fused silica capillary gas chromatography (GC) column on a Hewlett Packard Model 5993 Gas Chromatograph-Mass Spectrometer. Soil and liquid phase samples were extracted with an acetone-methyl alcohol mixture followed by gas stripping before injection into the Hewlett Packard Model 5993 Gas Chromatograph-Mass Spectrometer. The procedures permitted separation and identification of

\footnotetext{
1 The genus and species name of isolate JWI46 was not assigned as this could not be matched with any known microorganism in the BIOLOG ${ }^{\mathrm{TM}}$ database.
} 
straight-chain alkanes and PAHs. Percent residues were determined following drying and ignition at $550^{\circ} \mathrm{C}$ for $1 \mathrm{hr}$ using Standard Methods (American Public Health Association (APHA) 1981). TRPHs were evaluated using EPA Method 413.2 for total recoverable oil and grease (USEPA 1982). Twenty grams of each soil was extracted with $20 \mathrm{ml}$ of freon, and the resulting extract was analyzed by infrared spectrometry. 


\section{Results and Discussion}

\section{Isolation of PAH-Degrading Microorganisms from Ninth Avenue Soil}

Microorganisms were isolated on BSA containing phenanthrene, pyrene, fluorene, and 2-methylnaphthalene. BSA was also used to screen the isolates on a battery of PAHs and benzene-related compounds (benzene, ethylbezene, toluene, and xylene, collectively termed BTEX compounds). Of 21 isolates tested, 7 grew on all of the media; 7 grew on all media except toluene; 4 grew on all media except toluene and ethylbenzene; 2 grew on all media except phenanthrene, pyrene, and fluorene; and 1 exhibited mixed growth (Table 4).

The microorganisms listed in Table 4 were identified with the $\mathrm{BIOLOG}^{\mathrm{TM}}$ system (Table 5). The majority were members of the genus Pseudomonas. Many of these microorganisms were actually the same microorganism isolated on different media. Therefore, only nine different microorganisms were identified. They were four species of Pseudomonas and one species each of Moraxella, Sphingobacterium, Acinetobacter, Klebsiella, and Hemophilus.

\section{Enrichment and Screening Tests on Jennison- Wright Soils}

The total number of microorganisms expressed as CFUs per gram ODW of soil was determined for Jennison-Wright soil. Based on growth on PTYG agar, Jennison-Wright soil contained $1.1 \times 10^{7} \pm 1.6 \times 10^{6} \mathrm{CFUs/g}$ ODW soil. The microorganism recovered most frequently was Pseudomonas gladioli (65 percent of isolates). A second microorganism, Klebsiella pneumonia A, was also commonly isolated ( 30 percent of isolates).

Several microorganisms in Jennison-Wright soil used one or more of the priority PAHs as sole carbon and energy sources (Table 6). The best clearing was obtained around colonies growing on acenaphthene and phenanthrene, whereas colonies growing on fluoranthene, fluorene, and pyrene exhibited slight clearing of the PAHs around the colonies. Microorganisms from 
enrichments of Jennison-Wright soil grew at PAH mixture concentrations of 0.01 and 0.1 percent (Table 6).

Approximately 122 microorganisms were screened for their ability to use acenaphthene, fluoranthene, fluorene, phenanthrene, and pyrene. (The complete results for all of these microorganisms are given in the Table A1.) Results for microorganisms having positive activity against the priority PAHs are listed in Table 7. Isolate JWI46, a single microorganism isolated from consortium number 46 (Table A1), was active against all of the priority PAHs except acenaphthene within a 2 -week period. This microorganism was selected for study in carbon dioxide production studies. It was isolated on phenanthrene spray coated on BSA and was selected for amendment to slurries of Jennison-Wright soils in the bioslurry study.

\section{Activity Assays}

\section{Presumptive PAH degradation}

Only Treatment 1 containing yeast extract, phenanthrene, and the isolate gave a strong removal of oxygen with a concomitant accumulation of carbon dioxide (Figure 1). Treatment 2, which lacked yeast extract, also demonstrated some loss of oxygen and a slight increase in carbon dioxide over the test period, indicating that phenanthrene alone could serve as a carbon source. However, the changes in oxygen concentration after the second day were extremely small, and the carbon dioxide accumulated at a much lower rate than in Treatment 1. This indicated that the microbial isolate required yeast extract to obtain the maximum degradation rate. The controls lacking phenanthrene (Treatment 3), a carbon source (Treatment 4), and the uninoculated control (Treatment 5) were all quite similar. The drop in oxygen level between days 0 and 2 in both active treatments ( 1 and 2 ) and the control treatments ( 3 and 4 ) suggests that this reaction may represent a loss of the oxygen into the headspace or to autoxidation reactions. The fact that Treatments 3 through 5 did not accumulate detectable levels of carbon dioxide suggests that microbial activity was nonexistent in these treatments. Both yeast extract and a metabolizable PAH had to be present to obtain high levels of activity, since carbon dioxide production decreased sharply when either was omitted. Phenanthrene levels were not measured over the course of this study. Therefore, oxygen consumption and carbon dioxide accumulation in Treatment 1 cannot be attributed solely to phenanthrene mineralization; i.e., some mineralization of the yeast extract may also have occurred.

\section{PAH minerallzation}

Use of radiolabeled compounds provided a means of confirming mineralization. Since all nitrogen sources (ammonium sulfate, yeast extract) were omitted from the medium, any mineralization that occurred was carried out by 
resting (nongrowing) cells. Each isolate was able to mineralize the substrates tested with it (Table 8). Isolate JWI17 mineralized phenanthrene more rapidly and extensively than any of the other PAHs with either JWI46 or JWI17. Isolate JWI46 mineralized both fluoranthene and pyrene, each of which is structurally more complex than phenanthrene or fluorene (Figure 2). By comparison, isolate JWI17 mineralized fluorene very weakly.

\section{Bioslurry activity assays}

Microbial populations. Total populations of heterotrophic microorganisms on PTYG agar from each of the Jennison-Wright soil treatments showed very little difference between initial microbial population levels in the treatment containing only native microorganisms and those in the treatment containing native microorganisms plus the added isolate (Figure 3a). The data indicated that native heterotrophic microbial population levels in Jennison-Wright soil were at $10^{7}-10^{10} \mathrm{CFUs} / \mathrm{g}$ ODW of soil. Addition of an isolate at the level of $1 \times 10^{7} \mathrm{CFUs} / \mathrm{g}$ ODW did not add enough cells to the existing population for detection with the plate count technique (at best, this procedure is only accurate to within 1 to 2 orders of magnitude). The JWI46 isolate added to sterile Jennison-Wright soil survived when other native cells were not present. Treatment of the soil with mercuric chloride immediately decreased the level of native microorganisms present by 2 to 3 orders of magnitude and eliminated detectable microorganisms by the first week. This was paralleled by a lack of PAH-degrading activity in the mercuric chloride treatment (described in the following section).

Figures $3 \mathrm{~b}$ and $\mathrm{c}$ also provide a comparison of the phenanthrene-degrading microbial population levels present in the different Jennison-Wright soil treatments. Figure $3 \mathrm{~b}$ depicts the microorganisms recovered on BSA with phenanthrene dissolved in the medium, while Figure $3 \mathrm{c}$ indicates those recovered on EBSA with a spray coating of phenanthrene. BSA with phenanthrene dissolved in the medium recovered only those microorganisms using phenanthrene as a carbon source. The EBSA medium also contains yeast extract, so the microbes actually counted must be restricted to those clearing the PAH around the colony. The sterile soil with isolate JWI46 and the nonsterile soil containing JWI46 and the normal soil microflora had similar population levels. Thus, addition of isolate JWI46 to nonsterile soil did not appreciably change the detectable numbers of PAH-degrading microorganisms present in the nonsterile soil. The mercuric chloride treatment removed all microorganisms detectable on these media.

Effect of treatment on residues. Figure 4 presents a comparison of the effects of treatment over time on fixed, volatile, and total residues for Jennison-Wright bioslurry assay.

Fixed residues remained constant in all treatments over the entire 4-week incubation period (Figure 4). The poisoned control (Treatment 3) had 
somewhat lower levels of fixed residues than the two treatments with live cells. The treatment containing JWI46 only did not differ from the treatment with JWI46 plus native microorganisms (Treatments 1 and 2). Judging from the graph, percent volatile residues were limited and stable over the 4-week test period.

While not obvious from the graph, total residues in the treatments with live cells did not change significantly over 4 weeks. The treatment with native and added cells (Treatment 2 ) was approximately 10 percent higher than the treatment with JWI46 only (Treatment 1).

Effect of treatment on PAH removal. The mercuric chloride-treated control (Treatment 3 ) indicated that the priority PAH levels in the aqueous phase after 4 weeks of shaking did not differ significantly from those present initially (Figure 5). By contrast, when isolate JWI46 was inoculated into sterile Jennison-Wright soil, all but small residuals of fluoranthene and pyrene were removed from the aqueous phase. When isolate JWI46 was inoculated into nonsterile soil, the resulting microbial activity removed all of the priority PAHs from the aqueous phase.

The mean priority PAH levels in the soil before treatment were slightly lower than those in the soil treated with $\mathrm{HgCl}_{2}$ (Figure 6). However, except for phenanthrene and pyrene, differences were not significant. Sterile soil with isolate JWI46 (Treatment 1) showed measurable degradation of the PAHs. This treatment removed fewer PAHs than the treatment containing native microorganisms and JWI46 (Treatment 2). Based on the ability of JWI46 to remove priority PAHs in the screening test, very little acenaphthalene was expected to be removed, and fluorene should have degraded poorly. By contrast, fluoranthene, phenanthrene, and pyrene were expected to degrade readily. This agrees with the results of the bioslurry study, where fluoranthene, phenanthrene, and pyrene were each removed more completely than acenaphthalene and fluorene. However, it is also apparent that given sufficient time, JWI46 isolate alone would have removed all traces of fluorene, phenanthrene, fluoranthene, and pyrene. Moreover, isolate JWI46 may eventually have removed all of the acenaphthene.

PAHs dropped by one-third to one-half in the sterile soil containing isolate JWI46 in 4 weeks (Figure 6), while PAH levels fell by one-half to two-thirds in the slurry with native microorganisms and JWI46. Since JWI46 was so effective, the possibility exists that if all of the consortium from which JWI46 was obtained had been used, PAH removal may have been even more effective than with JWI46 alone.

The initial TRPH level for Jennison-Wright soil was $1,975 \pm 920.8 \mathrm{mg} / \mathrm{kg}$. This fell to $700 \pm 10 \mathrm{mg} / \mathrm{kg}$ in the treatment with sterile soil containing JWI46 and to $425 \pm 65 \mathrm{mg} / \mathrm{kg}$ in the treatment containing the native microorganisms and JWI46. By contrast, the TRPH level for the $\mathrm{HgCl}_{2}$-treated soil was 1,600 $\pm 600 \mathrm{mg} / \mathrm{kg}$, indicating that there was no substantial loss of TRPH in this treatment. Thus, all of the TRPH removal was biological. The combination of 
native microorganisms and JWI46 was significantly more effective in TRPH removal than the JWI46 isolate alone. However, the JWI46 isolate alone brought the TRPH level down to nearly one-third of the original value.

Assuming that the contribution to TRPH removal made by JWI46 alone (64.6percent removal) is the same in the treatment containing JWI46 plus native microorganisms (78.5-percent total removal), then the native microorganisms improved reduction by 78.5 to 64.6 percent, or 13.9 percent over that achieved by JWI46. With this interpretation, JWI46 made the major contribution to TRPH removal. 


\section{Conclusions}

A screening test was developed that demonstrated the presence of microorganisms using the priority PAHs present in a soil contaminated with these materials. When predominant microorganisms were isolated and screened for activity against the priority PAHs, individual isolates using several of the PAHs were identified. Analysis of PAH degradation with radioisotopes demonstrated that selected isolates were capable of mineralizing individual PAHs. Jennison-Wright soil, which contained a high level of PAH contamination, was examined in several different treatment slurries. Effective removal of priority PAHs was achieved with the selected JWI46 isolate alone and in combination with the native microorganisms. Very effective removal of TRPHs was achieved with JWI46 alone. Slightly more removal was obtained when native microorganisms were used in combination with JWI46. 


\section{References}

Aamand, J., Jorgensen, C., Arvin, E., and Jensen, B. K. (1989). "Microbial adaptation to degradation of hydrocarbons in polluted and unpolluted groundwater," Journal of Contaminant Hydrology 4, 299-312.

Allison, L. E. (1965). "Organic carbon." Methods of soil analysis, C. A. Black, ed., Agronomy Series No. 9, American Society of Agronomy, 1367-1378, Madison, WI.

American Public Health Association. (1981). "Standard methods for the examination of water and wastewater." 14th ed., New York.

Atlas, R. M. (1981). "Microbial degradation of petroleum hydrocarbons: an environmental perspective," Microbiological Reviews 45, 180-209.

Aust, S. D. (1990). "Degradation of environmental pollutants by Phanerochaete chrysosporium," Microbial Ecology 20, 197-209.

Bartha, R., and Atlas, R. M. (1977). "The microbiology of aquatic oil spills," Advances in Applied Microbiology 22, 225-226.

Bellin, C. A., and Rao, P. S. C. (1993). "Impact of bacterial biomass on contaminant sorption and transport in a subsurface soil," Applied and Environmental Microbiology 59, 1813-1820.

Bogardt, A. H., and Hemmingsen, B. B. (1992). "Enumeration of phenanthrene-degrading bacteria by an overlayer technique and its use in evaluation of petroleum-contaminated sites," Applied and Environmental Microbiology 58(8), 2579-2582.

Boldrin, B., Tiehm, A., and Fritzsche, C. (1993). "Degradation of phenanthrene, fluorene, fluoranthene, and pyrene by a Mycobacterium sp.," Applied and Environmental Microbiology 59(6), 1927-1930.

Bossert, I. D., and Bartha, R. (1984). "The fate of petroleum in soil ecosystems." Petroleum microbiology. R.M. Atlas, ed., Macmillan Publishing Company, New York, 436-473.

. (1986). "Structure-biodegradability relationships of polycyclic aromatic hydrocarbons in soil," Bulletin of Environmental Contamination and Toxicology 37, 490-495. 
Bossert, I. D., Kachel, M., and Bartha, R. (1984). "Fate of hydrocarbons during oily sludge disposal in soil," Applied and Environmental Microbiology 47, 763-767.

Bumpus, J. A. (1989). "Biodegradation of polycyclic aromatic hydrocarbons by Phanerochaete chrysosporium," Applied and Environmental Microbiology $55,154-158$.

Bumpus, J. A., Tien, M., Wright, D., and Aust, S. D. (1985). "Oxidation of persistent environmental pollutants by a white rot fungus," Science 228 , 1434-1436.

Carberry, J. B., and Lee, S. H. (1990). "Fate and transport of petroleum in the unsaturated soil zone under biotic and abiotic conditions," Water Science and Technology 22(6), 45-52.

Catallo, W. J., and Portier, R. J. (1992). "Use of indigenous and adapted microbial assemblages in the removal of organic chemicals from soils and sediments," Water Science and Technology 25(3), 229-237.

Catallo, W. J., Therberge, N. B., and Bender, M. E. (1989). "Sea level rise and hazardous wastes in the coastal zone: An ecological perspective." Proceedings of the sixth symposium on ocean and coastal management/ ASCE. VIMS Contribution No. 1511, Blacksburg, VA, 2, 1407-1420.

Cerniglia, C. E. (1984). "Microbial transformation of aromatic hydrocarbons." Petroleum microbiology. R.M. Atlas, ed., Macmillan Publishing Company, New York, 99-128.

DeLaune, R. D., Hambrick, G. A., III, and Patrick, W. H., Jr. (1980). "Degradation of hydrocarbons in oxidized and reduced sediments," Marine Pollution Bulletin 11, 103-106.

Desai, A. J., Patel, K. M., and Desai, J. D. (1988). "Emulsifier production by Pseudomonas fluorescens during the growth on hydrocarbons," Current Science 57, 500-501.

Dibble, J. T., and Bartha, R. (1979). "Effect of environmental parameters on the biodegradation of oil sludge," Applied and Environmental Microbiology 37, 729-739.

Edwards, N. T. (1983). "Polycyclic aromatic hydrocarbons (PAHs) in the terrestrial environment - a review," Journal of Environmental Quality 12(4), $427-441$.

Erickson, D. C., Loehr, R. C., and Neuhauser, E. F. (1993). "PAH loss during bioremediation of manufactured gas plant soils," Water Research 27(5), 911-919.

Epstein, S. S. (1983). "Environmental determinants of cancer," Cancer Research 34, 2425-2435. 
Fabacher, D. L., Schmitt, C. J., Besser, J. M., and Mac, M. J. (1988). “Chemical characterization and mutagenic properties of polycyclic aromatic compounds in sediment from tributaries of the Great Lakes," Environmental Toxicology and Chemistry 7, 529-543.

Fedorak, P. M., and Westlake, D. W. S. (1981). "Degradation of aromatics and saturates in crude oil by soil enrichments," Water, Air, and Soil Pollution 16, 367-375.

Field, J. A., de Jong, E., Costa, G. F., and de Bont, J. A. M. (1992). "Biodegradation of polycyclic aromatic hydrocarbons by new isolates of white rot fungi," Applied and Environmental Microbiology 58(7), 2219-2226.

George, E. J., and Neufeld, R. D. (1989). "Degradation of fluorene in soil by the fungus Phanerochaete chyrsosporium," Biotechnology and Bioengineering 33, 1306-1310.

Ghiorse, W. C., and Balkwill, D. L. (1983). "Enumeration and morphological characterization of bacteria indigenous to subsurface environments," Developments in Industrial Microbiology 24, 213-224.

Gibson, D. T., and Subramanian, V. (1984). "Microbial degradation of aromatic hydrocarbons." Microbial degradation of organic compounds. D. T. Gibson, ed., Marcel Dekker, New York, 181-252.

Grbic-Galic, D. (1989). "Microbial degradation of homocyclic and heterocyclic aromatic hydrocarbons under anaerobic conditions, developments in industrial microbiology." Journal of Industrial Microbiology, Suppl. 4. J. Cooney and O. Sebek, ed., 30, 237-253.

Grbic-Galic, D., Henry, S. M., Godsy, E. M., Edwards, E., and Mayer, K. P. (1989). "Anaerobic degradation of aromatic hydrocarbons and aerobic degradation of trichloroethylene by subsurface microorganisms." Proceedings of the meeting of the American Chemical Society. Boston.

Grbic-Galic, D., and Young, L. J. (1985). "Methane fermentation of ferulate and benzoate: anaerobic degradation pathways." Applied and Environmental Microbiology 50, 292-297.

Guerin, W. F., and Jones, G. E. (1988). "Mineralization of phenanthrene by a Mycobacterium sp.," Applied and Environmental Microbiology 54, 937-944.

Gunnison, D. (1991). "Evaluation of the potential use of microorganisms in the cleanup of petroleum hydrocarbon spills in soils," Technical Report EL91-13, U.S. Army Engineer Waterways Experiment Station, Vicksburg, MS.

Haemmerli, S. D., Leisola, M. S. A., Sanglard, D., and Feichter, A. (1986). "Oxidation of benzo(a)pyrene by extracellular ligninase of Phanerochaete chrysosporium," Journal of Biological Chemistry 261, 6900-6903.

Hammel, K. E., Green, B., and Gai, W. Z. (1991). "Ring fission of anthracene by a eukaryote," Proceedings of the National Academy of Science USA 88, 10605-10608. 
Hammel, K. E., Kalyanaraman, B., and Kirk, T. K. (1986). "Oxidation of polycyclic aromatic hydrocarbons and dibenzo[p]dioxins by Phanerochaete chrysosporuim," Journal of Biological Chemistry 261, 16948-16952.

Heitkamp, M. A., and Cerniglia, C. E. (1987). "Effects of chemical structure and exposure on the microbial degradation of polycyclic aromatic hydrocarbons in freshwater and estuarine ecosystems," Environmental Toxicology and Chemistry 6, 535-546.

(1988). "Mineralization of polycyclic aromatic hydrocarbons by a bacteriium isolated from sediment below an oil field," Applied and Environmental Microbiology 54, 1612-1614.

. (1989). "Polycyclic aromatic hydrocarbon degradation by a Mycobacterium sp. in microcosms containing sediment and water from a pristine ecosystem," Applied and Environmental Microbiology 55, 19681973.

Heitkamp, M. A., Franklin, W., and Cerniglia, C. E. (1988). "Microbial metabolism of polycyclic aromatic hydrocarbons: isolation and characterization of a pyrene-degrading bacterium," Applied and Environmental Microbiology 54, 2549-2555.

Heitkamp, M. A., Freeman, J. P., Miller, D. W., and Cerniglia, C. E. (1988). "Pyrene degradation by a Mycobacterium sp.: Identification of ring oxidation and ring fission products," Applied and Environmental Microbiology $54,2556-2565$.

Henrysson, T., and McCarty, P. L. (1993). "Influence of the endogenous storage lipid poly- $\beta$-hydroxybutyrate on the reducing power availability during cometabolism of trichloroethylene and naphthalene by resting methanotrophic mixed cultures," Applied and Environmental Microbiology 59, 16021606.

Herbes, S. E. (1977). "Partitioning of polycyclic aromatic hydrocarbons between dissolved and particulate phases in natural waters," Water Research 11, 493-496.

Herbes, S. E., and Schwall, L. R. (1978). "Microbial transformation of polycyclic aromatic hydrocarbons in pristine and petroleum-contaminated sediments," Applied and Environmental Microbiology 35, 306-316.

Hites, R. A., Laflamme, R., and Farrington, J. W. (1977). "Sedimentary polycyclic aromatic hydrocarbons: the historical record," Science 198, 829-831.

Hoffmann, G. R. (1982). "Mutagenicity testing in environmental toxicology," Environmental Science and Technology 16(10), 569A-574A.

Jones, J. G. (1977). "The long term effects of kerosine pollution on the microflora of a moorland soil," Journal of Applied Bacteriology 43, 123-128.

Laha, S., and Luthy, R. G. (1991). "Inhibition of phenanthrene mineralization by nonionic surfactants in soil-water systems," Environmental Science and Technology 25, 1920-1930. 
MacGillivray, A. R., and Shiaris, M. P. (1993). "Biotransformation of polycyclic aromatic hydrocarbons by yeasts isolated from coastal sediments," Applied and Environmental Microbiology 59, 1613-1618.

Martin, J. P., Haider, K., and Bondietti, E. (1992). "Properties of model humic acids synthsized by phenal oxidase and autooxidation of phenols and other compounds formed by soil fungi." Proceedings of the international meeting on humic substances. Nieuwesslius, Pudoc, Inc., Wageningen, Belgium.

McCann, J., and Ames, B. N. (1976). "Detection of carcinogens as mutagens in the Salmonella/microsome test: assay of 300 chemicals: discussion," Proceedings of the National Academy of Science 73, 950-954.

McCann, J., Choi, Yamasaki, E., and Ames, B. N. (1975). "Detection of carcinogens as mutagens in the Salmonella/microsome test: assay of 300 chemicals," Proceedings of the National Academy of Science 72, 51355139.

Means, J. C., Wood, S. G., Hassett, J. J., and Banwart, W. L. (1980). "Sorption of polynuclear aromatic hydrocarbons by sediments and soils," Environmental Science and Technology 14, 1525-1528.

Mihelcic, J. R., and Luthy, R. G. (1986). "Adsorption and degradation of PAH compounds in soil, progress report," prepared for U.S. Department of Energy, by Department of Civil Engineering, Carnigie-Mellon University, Pittsburgh.

(1988a). "Degradation of polycyclic aromatic hydrocarbon compounds under various redox conditions in soil-water systems," Applied and Environmental Microbiology 54, 1182-1187.

(1988b). "Microbial degradation of acenaphthene and naphthalene under denitrification conditions in soil-water systems," Applied and Environmental Microbiology 54, 1188-1198.

Mueller, J. G., Chapman, P. J., and Pritchard, P. H. (1989). "Creosote contaminated sites: their potential for bioremediation," Environmental Science and Technology 23, 1197-1201.

Mueller, J. G., Lantz, S. E., Blattmann, B. O., and Chapman, P. J. (1991a). "Bench-scale evaluation of alternative biological treatment processes for the remediation of pentachlorophenol- and creosote-contaminated materials: solid phase bioremediation," Environmental Science and Technology 25, 1045-1055.

Mueller, J. G., Middaugh, D. P., Lantz, S. E., and Chapman, P. J. (1991b). "Biodegradation of creosote and pentachlorophenol in contaminated groundwater: chemical and biological assessment," Applied and Environmental Microbiology 57, 1277-1285.

Mueller, J. G., Lantz, S. E., Ross, D., Colvin, R. J., Middaugh, D. P., and Pritchard, P. H. (1993). "Strategy using bioreactors and specially selected microorganisms for bioremediation of groundwater contaminated with creosote and pentachlorophenol," Environmental Science 27, 691-698. 
Narro, M. L., Cerniglia, C. E., van Baalen, C., and Gibson, D. T. (1992a). "Evidence for an NIH shift in oxidation of naphthalene by the marine cyanobacterium Oscillatoria sp. strain JCM," Applied and Environmental Microbiology 58(4), 1360-1363. . (1992b). "Metabolism of phenanthrene by the marine cyanobacterium Agmenellum quadruplicatum PR-6," Applied and Environmental Microbiology 58(4), 1351-1359.

National Academy of Sciences. (1984). "Fate of petroleum in the marine environment," Washington, DC.

Patrick, W. H., Jr. (1958). "Modification of method of particle size analysis," Proceedings of the Soil Science Society of America 4, 366-367.

Pfennig, N. (1974). "Rhodopseudomonas globiformis sp. n., a new species of the Rhodospirillaceae," Archiv für Mikrobiologie 100, 197-206.

Pothuluri, J. V., Freeman, J. P., Evans, F. E., and Cerniglia, C. E. (1992). "Fungal metabolism of acenaphthene by Cunninghamella elegans," Applied and Environmental Microbiology 58(11), 3654-3659.

Qui, X., and McFarland, M. J. (1991). "Bound residue formation in PAH contaminated soil composting using Phanaerochaete chrysosporium," Hazardous Wastes and Hazardous Materials 8, 1165-126.

Ridgeway, H. F., Phipps, D. W., Safarik, J., Haag, F., Reinhard, M., Ball, , and McCarty, P. (1988). "Investigation of the transport and fate of gasoline hydrocarbon pollutants in groundwater," final report submitted by Orange County Water District to U.S. Geological Survey, Reston, VA.

Rinkus, S. J., and Legator, M. S. (1979). "Chemical characterization of 465 known or suspected carcinogens and their correlation with mutagenic activity in the Salmonella typhimurium system," Cancer Research 39, 32893318.

Rosenberg, E., Zuckerberg, A., Rubinovitz, C., and Gutnik, D. L. (1979). "Emulsifier of Arthrobacter RAG-1: isolation and emulsifying properties," Applied and Environmental Microbiology 37, 403-408.

Sanseverino, J., Applegate, B. M., King, J. M. H., and Sayler, G. S. (1993). "Plasmid-mediated mineralization of naphthalene, phenanthrene, and anthracene," Applied and Environmental Microbiology 59(6), 1931-1937.

Swartz, R. C., Schults, D. W., Dewitt, T. H., Ditsworth, G. R., and Lamberson, J. O. (1990). "Toxicity of fluoranthene in sediment to marine amphipods: a test of the equilibrium partitioning approach to sediment quality criteria," Environmental Toxicology and Chemistry 9, 1071-1080.

Song, H. G., Wang, X., and Bartha, R. (1990). "Bioremediation of terrestrial fuel spills," Applied and Environmental Microbiology 56, 652-656.

Stroo, H. F. (1992). "Biotechnology and hazardous waste treatment," Journal of Environmental Quality 21(2), 167-175. 
Tagatz, M. E., Plaia, G. R., Deans, C. H., and Lores, E. M. (1983). "Toxicity of creosote-contaminated sediment to field- and laboratory-colonized estuarine benthic communities," Environmental Toxicology and Chemistry 2, 441-450.

U.S. Environmental Protection Agency. (1978). "Hazardous waste. Proposed guidelines and proposal on identification and listing," Federal register, 43, 243.

. (1982). "Test Methods. Technical Additions to Methods for Chemical Analysis of Water and Wastes," Technical Report EPA-600/4-82055, Environmental Monitoring and Support Laboratory, Cincinnati.

van Gemerden, H. (1968). "Growth measurements of Chromatium cultures," Archiv für Mikrobiologie 64, 103-110.

Volkering, F., Breure, A., Sterkenburg, A., and van Andei, J. G. (1992). "Microbial degradation of polycyclic aromatic hydrocarbons: effect of substrate availability on bacterial growth kinetics," Applied Microbiology and Biotechnology 36, 548-552.

Wang, X., Yu, and Bartha, R. (1990). "Affect of bioremediation on polycyclic aromatic hydrocarbon residues in soil," Environmental Science and Technology 24(7), 1086-1089.

Ward, D. M., and Brock, T. D. (1978). "Anaerobic metabolism of hexadecane in marine sediments," Geomicrobiology Journal 1, 1-9.

Weissenfels, W. D., Klewer, H. J., and Langhoff, J. (1992). "Adsorption of polycyclic aromatic hydrocarbons (PAHs) by soil particles: influence on biodegradability and biotoxicity," Applied Microbiology and Biotechnology 36, 689-696.

Westlake, D. W. S., Jobson, A. M., and Cook, F. D. (1978). "In situ degradation of oil in a soil of the boreal region of the Northwest Territories," Canadian Journal of Microbiology 24, 254-260.

Wilson, S. C., and Jones, K. C. (1993). "Bioremediation of soil contaminated with polynuclear aromatic hydrocarbons (PAHs): A review," Environmental Pollution 81, 229-249.

Zajick, J. E., and Mahomedy, A. Y. (1984). "Biosurfactants: intermediates in the biosynthesis of amphipathic molecules in microbes." Petroleum microbiology. R. M. Atlas, ed., Macmillan, New York, 221-297.

Zappi, M. E., Gunnison, D., Teeter, C. L. (1993). "A labotatory evaluation of bioslurry systems for treatment of a petroleum hydcarbon contaminated soil," manuscript submitted for publication in Annals of the New York Academy of Science. 


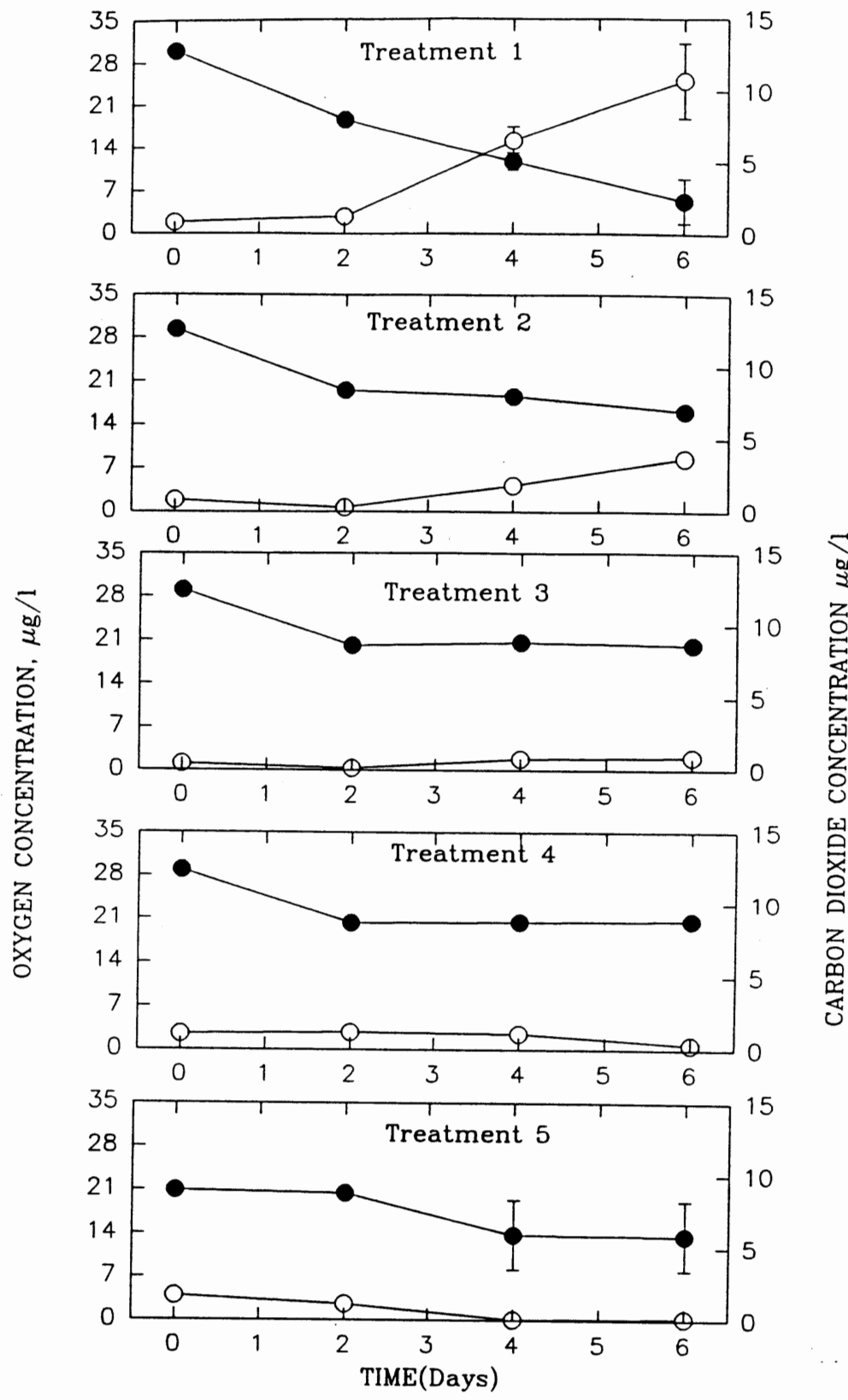

Figure 1. Oxygen consumption $(\bullet)$ carbon dioxide evolution $(0)$ during microbial degradation of phenanthrene by isolate JWI46. Treatment 1 - EBSM containing inoculum, phenanthrene yeast extract; Treatment 2 - EBSM containing inoculum and phenanthrene without yeast extract; Treatment 3 - EBSM containing inoculum and yeast extract only; Treatment 4 - EBSM containing phenanthrene and yeast extract, but left uninoculated to provide a chemical control; Treatment 5 - EBSM with inoculum, but without phenanthrene or yeast extract to provide a biological control. Values plotted are means of three replicates. Bars are standard errors of each mean 


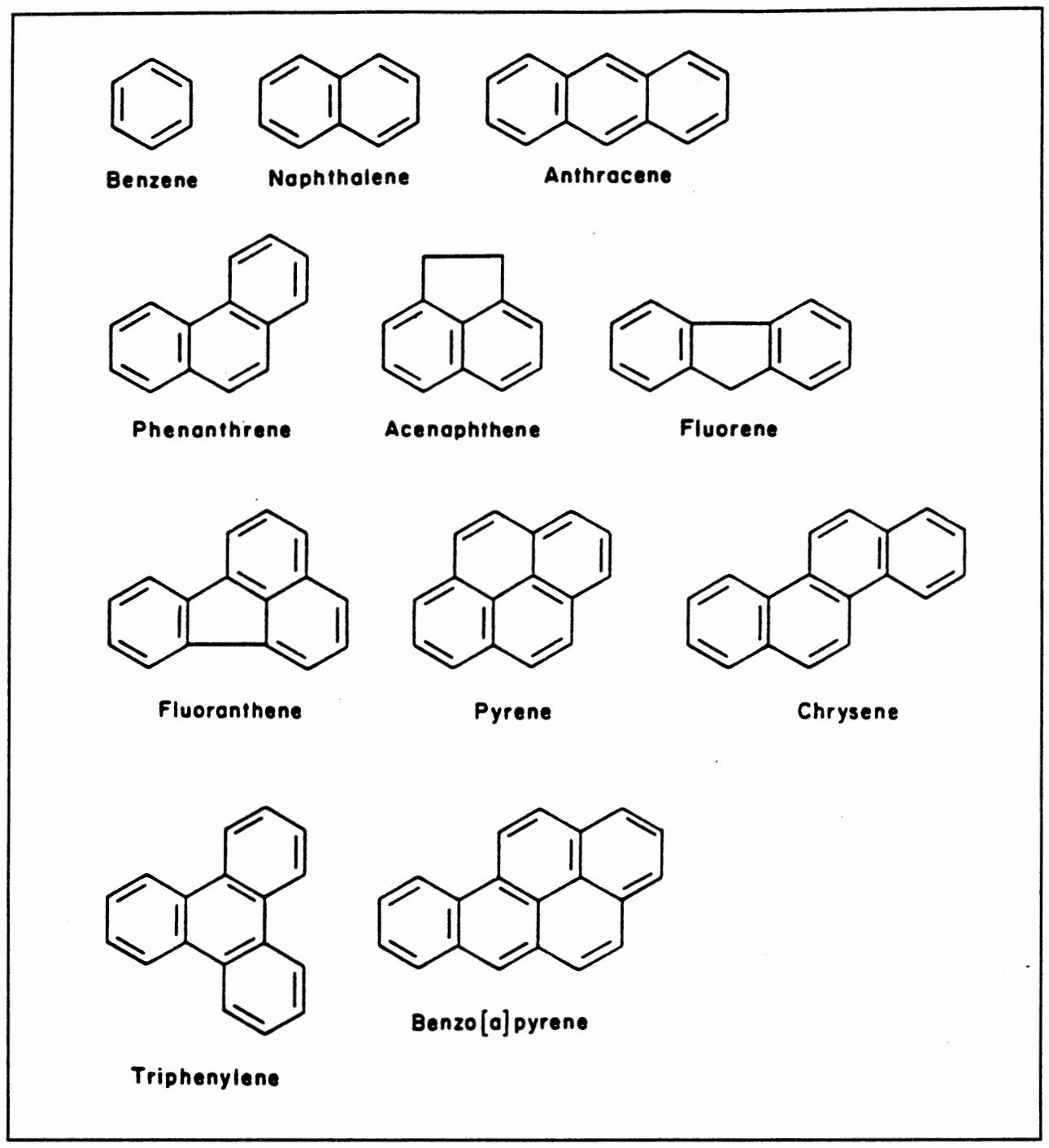

Figure 2. Structures of benzene and several major polycyclic aromatic hydrocarbons 


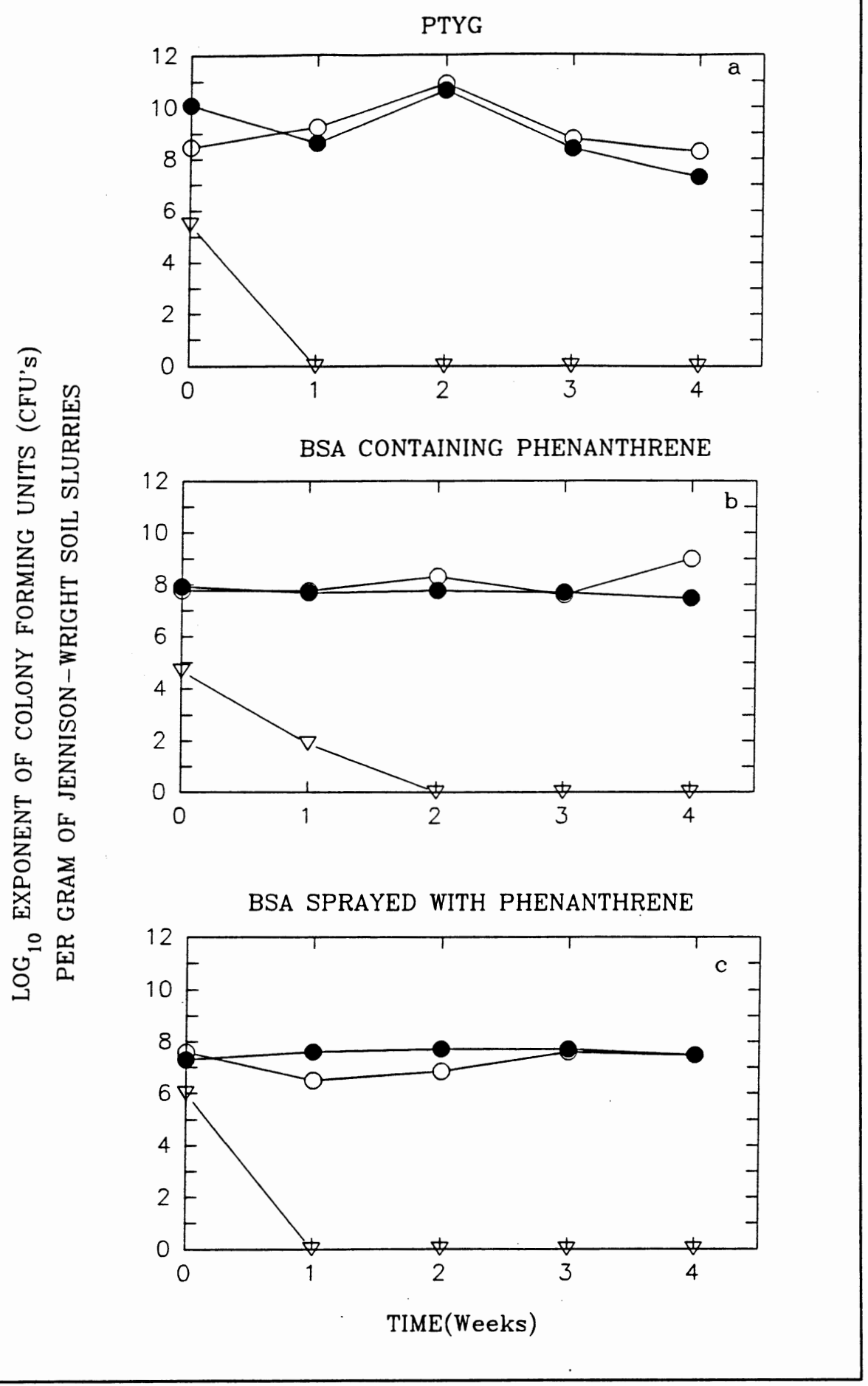

Figure 3. Microorganisms recovered from Jennison-Wright soils. (a) PTYG agar; (b) BSA containing phenanthrene dissolved in the medium; (c) EBSA sprayed with phenanthrene. $0=$ sterile soil with isolate JWI46; $\bullet=$ nonsterile soil with isolate JWI46; and $\nabla=$ sterile soil with mercuric chloride 


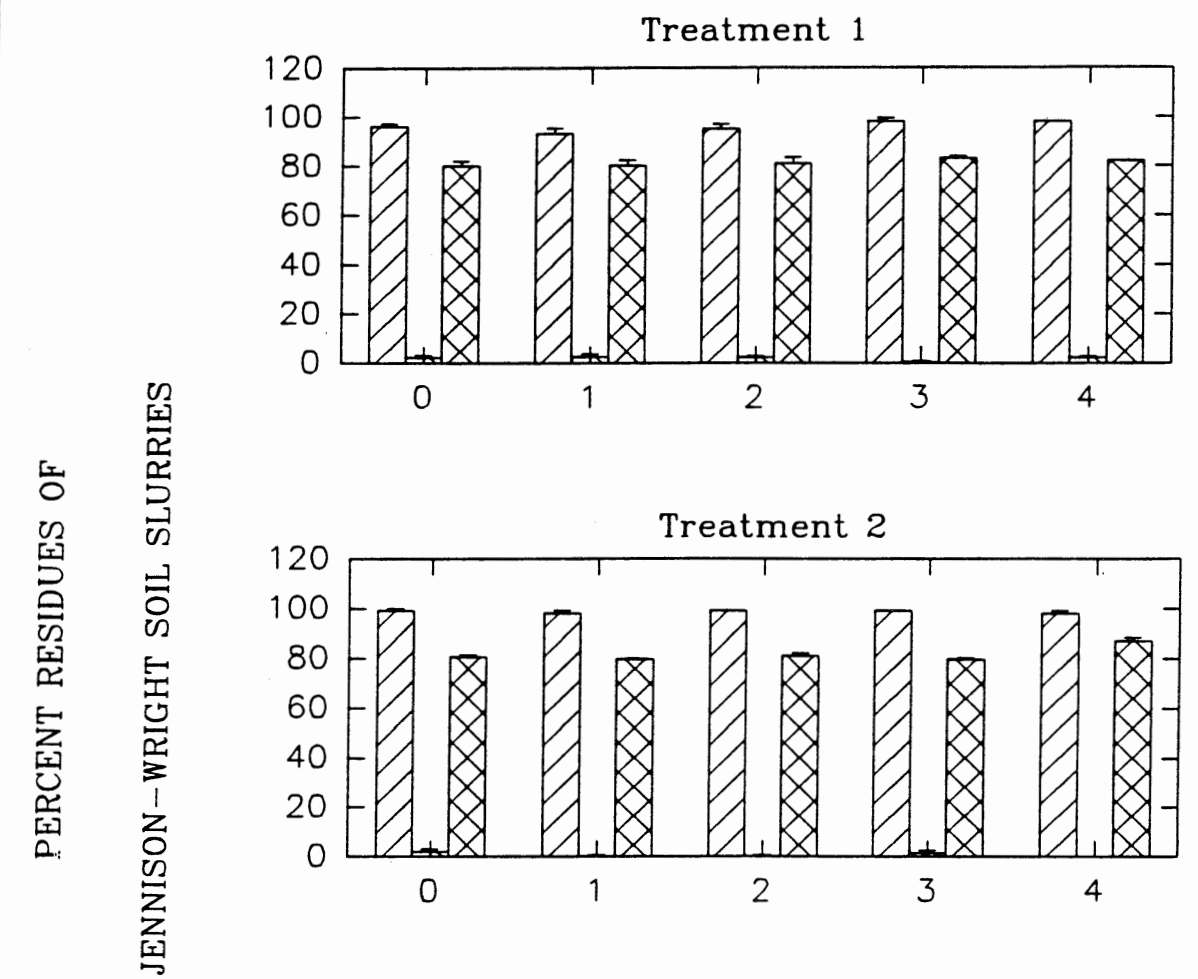

Treatment 3

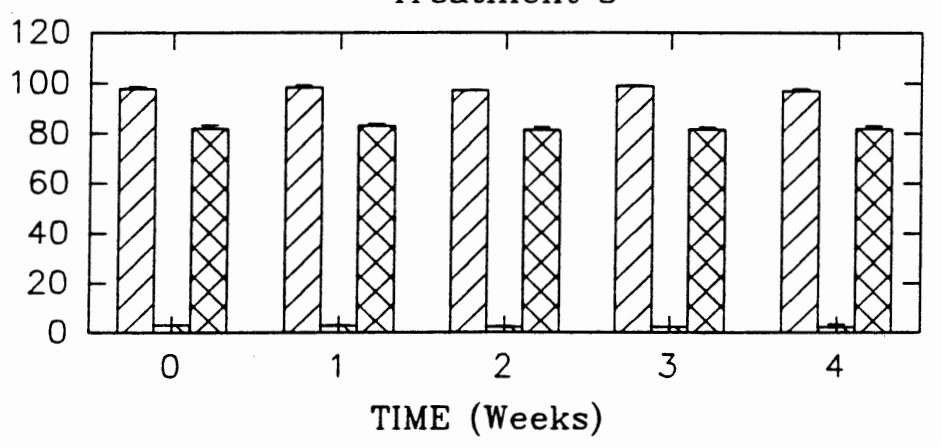

$\square$ \% TOTAL RESIDUES $\triangle$ \% VOLATILE RESIDUES $\square$ \% FIXED RESIDUES

Figure 4. Percent fixed, volatile, and total residues from Jennison-Wright soil after treatment. Treatment 1 - sterile soil with isolate JWI46; Treatment 2 - nonsterile soil with isolate JWI46; Treatment 3 - sterile soil with mercuric chloride 


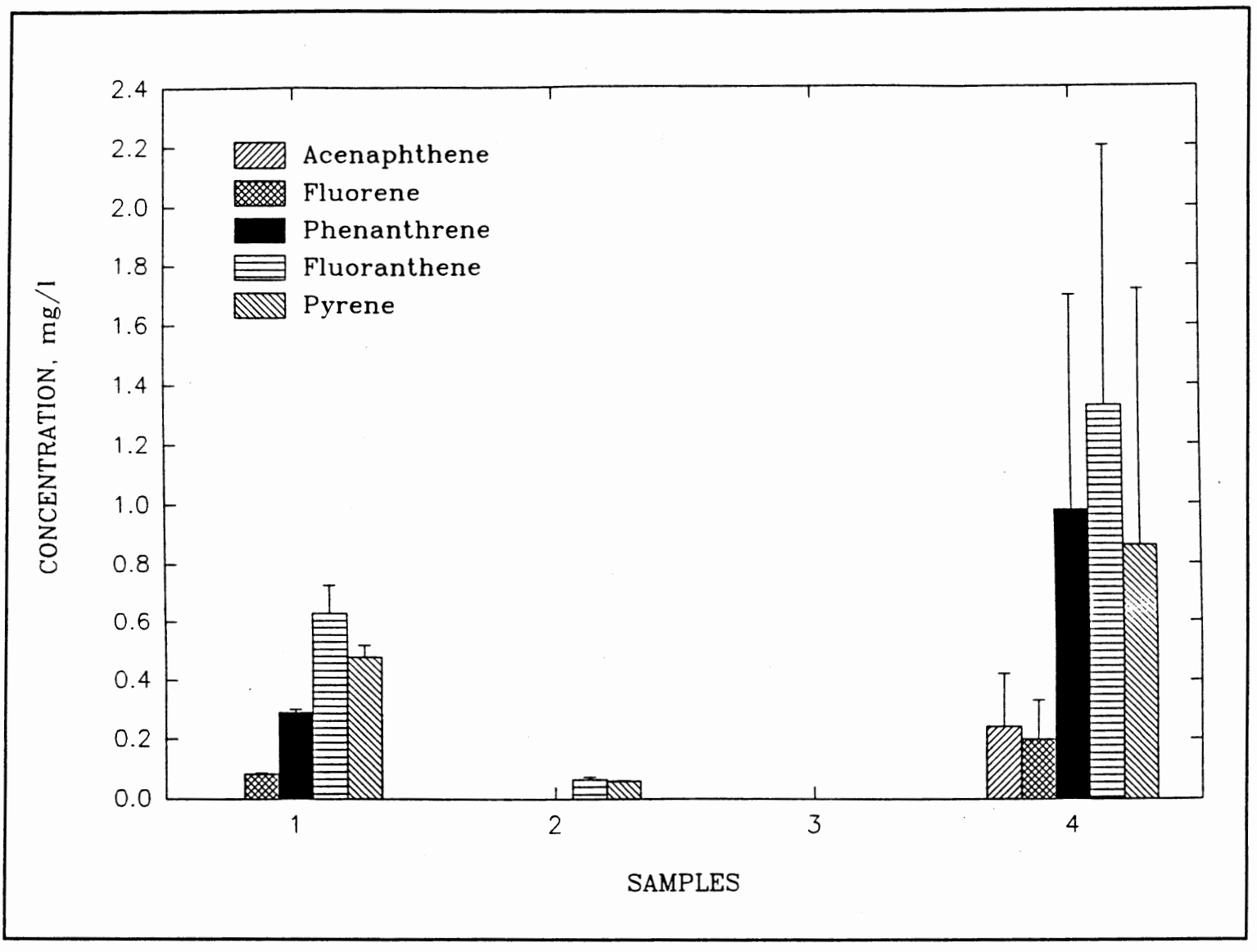

Figure 5. Priority PAH levels in the liquid phase of Jennison-Wright soil in the bioslurry study. Sample 1 - enriched reverse osmosis water exposed to soil for $1 \mathrm{hr}$; Sample 2 - water after 4 weeks with sterile soil and isolate JWI46 (Treatment 2); Sample 4 - water after 4 weeks with sterile soil and mercuric chloride (Treatment 3). 


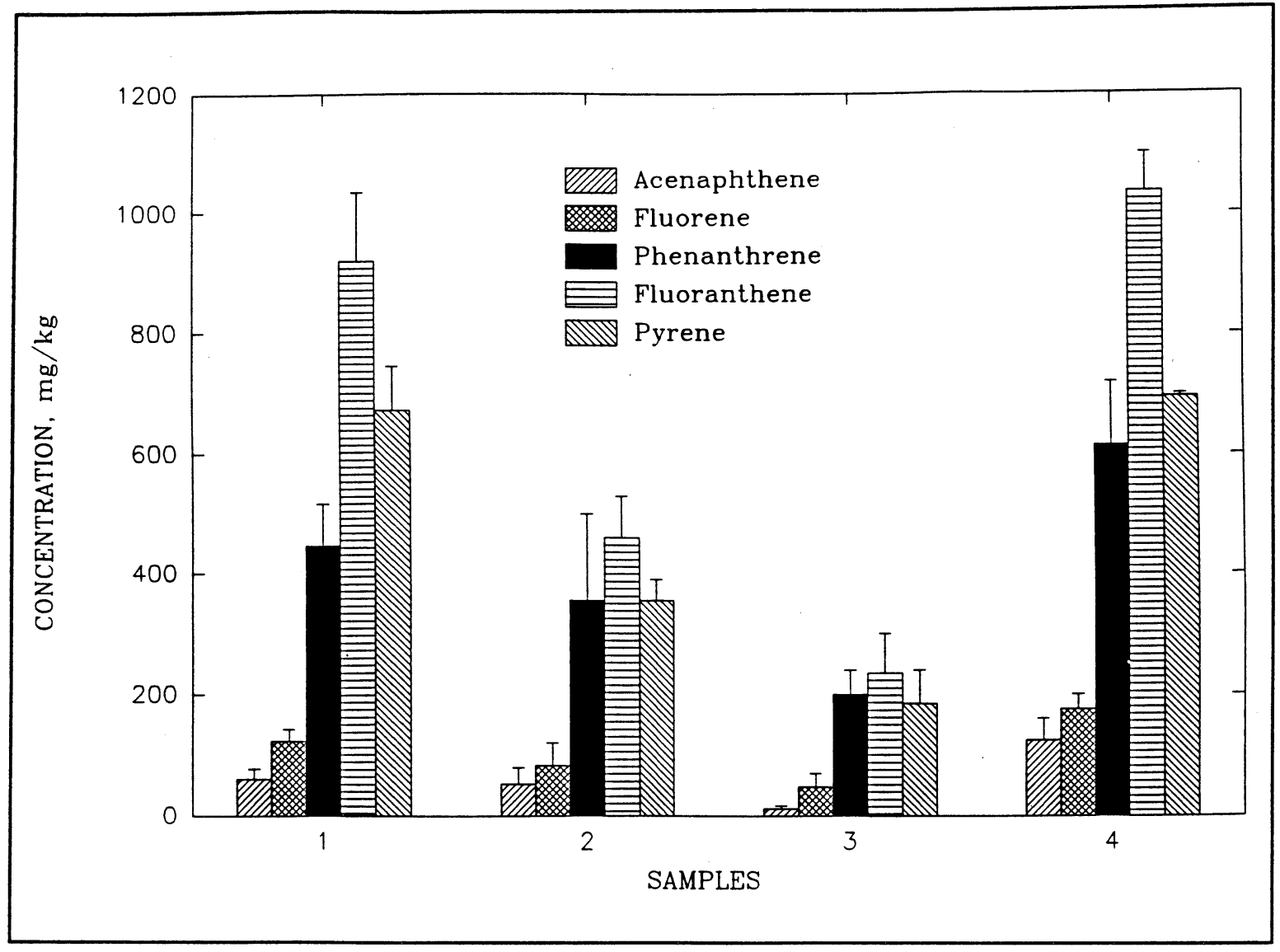

Figure 6. Priority PAH levels in the solid phase of Jennison-Wright soil in the bioslurry study. Sample 1 - soil prior to treatment; Sample 2 - sterile soil after 4 weeks with isolate JWI46 (Treatment 1); Sample 3 - nonsterile soil after 4 weeks with isolate JWI46 (Treatment 2); Sample 4 - sterile soil after 4 weeks with mercuric chloride (Treatment 3) 


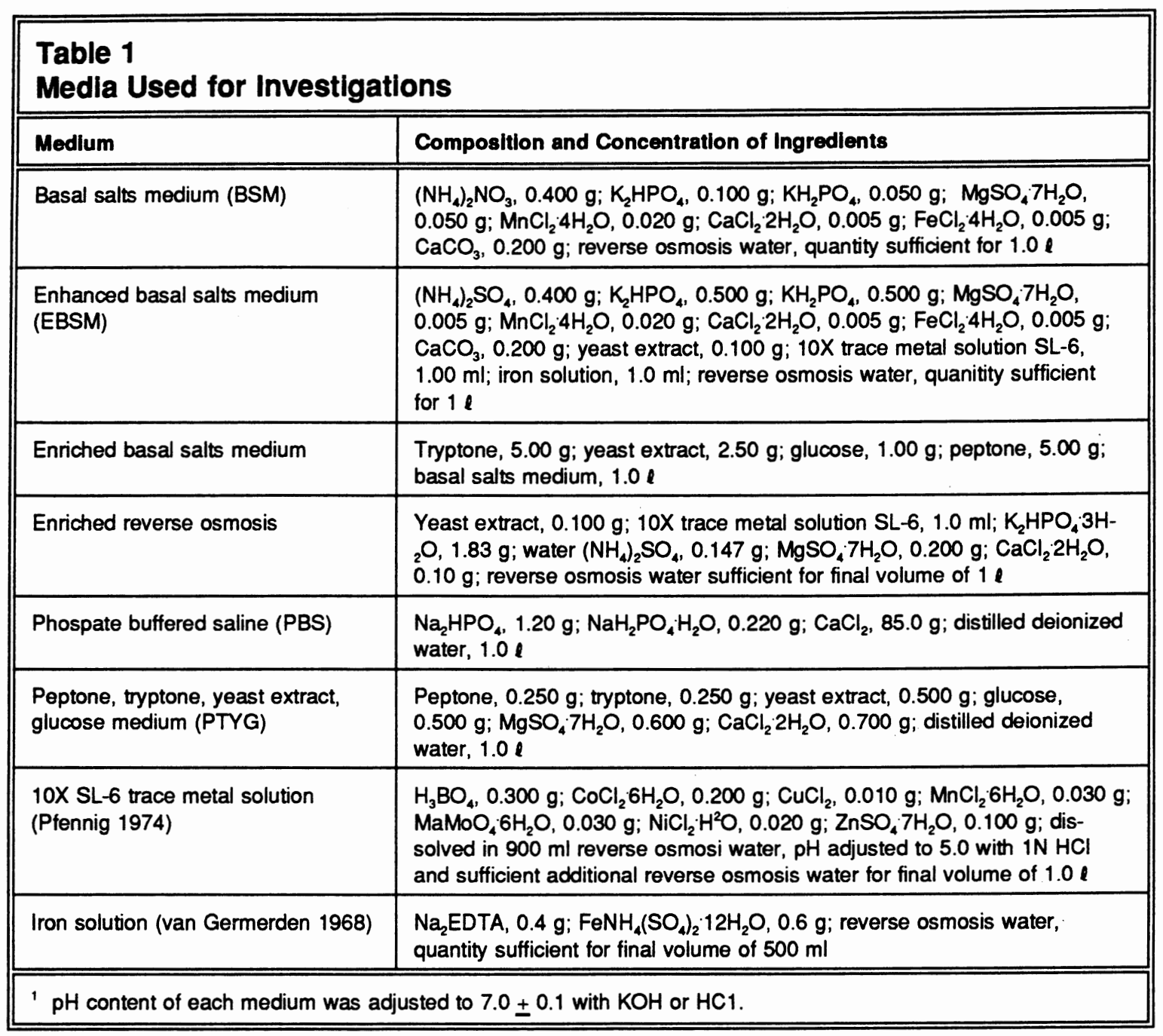




\begin{tabular}{|c|c|}
\hline \multicolumn{2}{|c|}{$\begin{array}{l}\text { Table } 2 \\
\text { PAH Content of Ninth Avenue Soll }\end{array}$} \\
\hline PAH & Concentration, $\mathrm{mg} / \mathrm{kg}$ \\
\hline Acenapthene & 14 \\
\hline Benzo(b)fluoranthene & 14 \\
\hline Benzo(k)fluoranthene & $<1.0$ \\
\hline Fluoranthene & $28^{1}$ \\
\hline Fluorene & 18 \\
\hline 2-Methylnaphthalene & $140^{\prime}$ \\
\hline Naphthalene & $49^{\prime}$ \\
\hline Phenanathrene & $55^{1}$ \\
\hline Pyrene & $24^{1}$ \\
\hline
\end{tabular}




\begin{tabular}{||l|l||}
\hline \hline \multicolumn{2}{|l|}{ Table 3 } \\
PAH Content of Jennison-Wright Soll \\
\hline \hline PAH & Concentration, $\mathbf{~ m g} / \mathbf{k g}$ \\
\hline \hline Acenaphthene & $110^{\prime}$ \\
\hline Acenaphthylene & 7 \\
\hline Anthracene & 65 \\
\hline Benzo(a)anthracene & 83 \\
\hline Benzo(b)fluoranthene & 25 \\
\hline Benzo(g,h,i)perylene & 22 \\
\hline Benzo(k)fluoranthene & $282^{2}$ \\
\hline Benzo(a)pyrene & 80 \\
\hline Chrysene & 69 \\
\hline Dibenzo(a,h)anthracene & ND \\
\hline Fluoranthene & $220^{\prime}$ \\
\hline Fluorene & $94^{\prime}$ \\
\hline Indeno(1,2,3-c,d)pyrene & 22 \\
\hline 2-Methylnaphthalene & 30 \\
\hline Phenanthrene & $260^{\prime}$ \\
\hline Pyrene & $140^{\prime}$ \\
\hline \hline I Selected as a priority PAH for this soil. \\
2 Not selected as a priority PAH for this soil because the pure compound was not available in \\
quantity sufficient for use in the work. & \\
\hline ND = not detected. & \\
\hline
\end{tabular}




\begin{tabular}{|c|c|c|c|c|c|c|c|c|c|c|}
\hline \multirow[b]{2}{*}{ Colony ID } & \multirow[b]{2}{*}{ Description } & \multirow[b]{2}{*}{ Source } & \multicolumn{8}{|c|}{ Growth on Test Medium } \\
\hline & & & PTYG & PHN & PYR & FLR & EBZ & TOL & XYL & 2-MN \\
\hline $9 A V-1-C 1$ & Opq. Smth. & $2-M$ & + & + & + & + & + & + & + & + \\
\hline $9 A V-1-C 2$ & Trns., Smth. & $2-M$ & + & + & + & + & + & + & + & + \\
\hline $9 A V-2-C 1$ & Opq., Smth. & $2-M$ & + & + & + & + & + & - & + & + \\
\hline $9 A V-2-C 2$ & Trns., Op, Smth. & $2-M$ & + & + & + & $+1-$ & + & - & + & + \\
\hline 9AV-2-C3 & Yllw, Smth. & $2-M$ & + & + & + & + & + & - & + & + \\
\hline $9 A V-2-C 4$ & Trns., Smth. & $\mathrm{FL}$ & + & + & + & + & + & + & + & + \\
\hline $9 A V-3-C 1$ & Opq., Smth. & PTYG & + & + & + & + & - & - & + & + \\
\hline $9 A V-3-C 2$ & Yllw, Smth. & PTYG & + & + & + & + & + & - & + & + \\
\hline 9AV-3-C3 & Trns., Smth. & TOL & + & + & + & + & + & + & + & + \\
\hline $9 A V-4-C 1$ & Opq., Smth. & PTYG & + & + & + & + & - & - & + & + \\
\hline $9 A V-4-C 2$ & Yllw, Smth. & PTYG & + & + & + & + & + & - & + & + \\
\hline $9 A V-4-C 3$ & Opq., Smth., Lrg. & TOL & + & - & - & - & + & + & + & + \\
\hline 9AV-4-C4 & Trns., Op., Smth. & $X Y L$ & + & + & + & + & + & + & + & + \\
\hline 9AV-4-C5 & Trns., Smth. & EBZ & + & + & + & + & + & + & + & + \\
\hline $9 A V-5-C 1$ & Opq., Smth., Lrg. & $X Y L$ & + & + & + & + & + & - & + & + \\
\hline $9 A V-5-C 2$ & Opq., Smth., Sml. & TOL & + & - & - & - & + & + & + & + \\
\hline \multicolumn{11}{|c|}{ (Continue } \\
\hline
\end{tabular}




\begin{tabular}{|c|c|c|c|c|c|c|c|c|c|c|}
\hline \multirow[b]{2}{*}{ Colony ID } & \multirow[b]{2}{*}{ Description } & \multirow[b]{2}{*}{ Source } & \multicolumn{8}{|c|}{ Growth on Test Medium } \\
\hline & & & PTYG & PHN & PYR & FLR & EBZ & TOL & XYL & 2-MIN \\
\hline 9AV-5-C3 & Trns., Smth. & PHN & + & + & + & + & + & + & + & + \\
\hline 9AV-6-C1 & Opq., Smth. & PTYG & + & + & + & + & - & - & + & + \\
\hline $9 A V-6-C 2$ & Opq., Smth., Lrg. & PTYG & + & + & + & + & + & - & + & + \\
\hline 9AV-6-C3 & Trms., Opq., Smth. & $2-M$ & + & + & + & + & - & - & + & + \\
\hline $9 A V-6-C 4$ & Yllw., Smth. & PTYG & + & + & + & + & $+1-$ & - & - & + \\
\hline
\end{tabular}




\begin{tabular}{|c|c|c|}
\hline \multicolumn{3}{|c|}{$\begin{array}{l}\text { Table } 5 \\
\text { Identification of Microorganisms Obtained from Ninth Avenue } \\
\text { Soil In Initial Isolation and Screening Test }\end{array}$} \\
\hline Colony ID & Source Medium' & Name of Microorganism \\
\hline $9 A V-1-C 1$ & $2-M$ & Acinetobacter genospecies 6 \\
\hline $9 A V-1-C 2$ & 2-M & Pseudomonas paucimoblis subgroup A \\
\hline $9 A V-2-C 1$ & $2-M$ & Pseudomonas putida subgroup B \\
\hline $9 A V-2-C 2$ & $2-M$ & Sphingobacterium multivorum \\
\hline $9 A V-2-C 3$ & $2-M$ & Pseudomonas vesicularis \\
\hline $9 A V-2-C 4$ & $\mathrm{FL}$ & Sphingobacterium multivorum \\
\hline 9AV-3-C1 & PTYG & Haemophilis ducreyi \\
\hline 9AV-3-C2 & PTYG & Moraxella atlantae \\
\hline 9AV-3-C3 & TOL & Pseudomonas vesicularis \\
\hline $9 A V-4-C_{1}$ & PTYG & Pseudomonas vesicularis \\
\hline $9 A V-4-C 2$ & PTYG & Pseudomonas vesicularis \\
\hline $9 A V-4-C 3$ & TOL & Insufficient Growth for Testing \\
\hline $9 A V-4-C 4$ & $X Y L$ & Pseudomonas vesicularis \\
\hline $9 A V-4-C 5$ & EBZ & Moraxella atlantae \\
\hline $9 A V-5-C 1$ & $X Y L$ & Pseudomonas vesicularis \\
\hline $9 A V-5-C 2$ & TOL & Klebsiella terrigena \\
\hline $9 A V-5-C 3$ & PHN & Pseudomonas marginalis \\
\hline $9 A V-6-C 1$ & PTYG & Acinetobacter genospecies 12 \\
\hline $9 A V-6-C 2$ & PTYG & Moraxella atlantae \\
\hline 9AV-6-C3 & $2-M$ & Insufficient Growth for Testing \\
\hline $9 A V-6-C 4$ & PTYG & Pseudomonas vesicularis \\
\hline
\end{tabular}




\begin{tabular}{|c|c|c|c|c|c|c|}
\hline \multicolumn{7}{|c|}{$\begin{array}{l}\text { Table } 6 \\
\text { Recovery of Priority PAH-Degrading Microorganisms from Jennison-Wright Soll }\end{array}$} \\
\hline \multirow[b]{3}{*}{ Priority PAH } & \multirow{2}{*}{\multicolumn{2}{|c|}{ Soll }} & \multicolumn{4}{|c|}{ Enrichment Cultures } \\
\hline & & & \multicolumn{2}{|c|}{0.01 Percent } & \multicolumn{2}{|c|}{0.1 Percent } \\
\hline & $\begin{array}{l}\text { No. Colonies } \\
\left(M_{ \pm} \text {S.E.) }\right.\end{array}$ & $\begin{array}{l}\text { No. Cleared' } \\
(M \pm S . E .)\end{array}$ & $\begin{array}{l}\text { No. Colonies } \\
(M \pm S . E .)\end{array}$ & $\begin{array}{l}\text { No. Cleared } \\
(M \pm \text { S.E. })\end{array}$ & $\begin{array}{l}\text { No. Colonles } \\
(M \pm S . E .)\end{array}$ & $\begin{array}{l}\text { No. Cleared } \\
(M \pm \text { S.E.) }\end{array}$ \\
\hline Acenaphthene & $\begin{array}{l}1.0 \times 10^{5} \pm \\
9.3 \times 10^{4}\end{array}$ & $6.0 \pm 5.3$ & $\begin{array}{l}1.3 \times 10^{8} \pm \\
9.8 \times 10^{7}\end{array}$ & 0 & $\begin{array}{l}4.2 \times 10^{7} \\
2.2 \times 10^{7} \\
\end{array}$ & $\begin{array}{l}6.5 \pm 1.5 \\
+1 \text { whole }\end{array}$ \\
\hline Fluoranthene & $\begin{array}{l}1.2 \times 10^{8} \pm \\
1.0 \times 10^{8}\end{array}$ & Unclear & $\begin{array}{l}1.6 \times 10^{8} \pm \\
7.0 \times 10^{7}\end{array}$ & $1.0 \pm 1.0$ & $\begin{array}{l}4.7 \times 10^{7} \\
2.9 \times 10^{7}\end{array}$ & 0 \\
\hline Fluorene & $\begin{array}{l}2.9 \times 10^{3} \pm \\
1.4 \times 10^{7}\end{array}$ & Unclear & $\begin{array}{l}1.8 \times 10^{7} \pm \\
1.1 \times 10^{7}\end{array}$ & 0 & $\begin{array}{l}9.1 \times 10^{5} \\
6.5 \times 10^{5}\end{array}$ & Unclear \\
\hline Phenanthrene & $\begin{array}{l}4.1 \times 10^{4} \pm \\
3.0 \times 10^{4}\end{array}$ & $14.0 \pm 11.2$ & $\begin{array}{l}3.7 \times 10^{5} \pm \\
3.6 \times 10^{5}\end{array}$ & $3.7 \pm 3.7$ & $\begin{array}{l}1.3 \times 10^{4} \\
8.8 \times 10^{3}\end{array}$ & $62 \pm 59$ \\
\hline Pyrene & $\begin{array}{l}2.3 \times 10^{7} \pm \\
2.0 \times 10^{7}\end{array}$ & Unclear & $\begin{array}{l}1.3 \times 10^{8} \\
1.3 \times 10^{8}\end{array}$ & 0 & $\begin{array}{l}1.8 \times 10^{7} \\
1.6 \times 10^{7}\end{array}$ & $1.0 \pm 1.0$ \\
\hline
\end{tabular}




\begin{tabular}{||l|l||}
\hline $\begin{array}{l}\text { Table } 7 \\
\text { Summary of Spectrum of Activity of 122 PAH-Degrading Micro- } \\
\text { organisms Isolated from Jennison-Wright Soil. }\end{array}$ \\
\hline \hline Compound or Combination of Compounds & $\begin{array}{l}\text { No. of Isolates Active on } \\
\text { Compound }\end{array}$ \\
\hline \hline Acenaphthene & 38 \\
\hline Fluoranthene & 0 \\
\hline Fluorene & 6 \\
\hline Phenanthrene & 38 \\
\hline Pyrene & 0 \\
\hline Acenaphthene, Fluoranthene, Fluorene & 3 \\
\hline Fluoranthene, Fluorene, Phenanthrene, Pyrene & 3 \\
\hline Acenaphthene, Fluoranthene, Fluorene, Phenanthrene, Pyrene & 2 \\
\hline
\end{tabular}

\begin{tabular}{|c|c|c|}
\hline \multicolumn{3}{|c|}{$\begin{array}{l}\text { Table } 8 \\
\text { Mineralization Rates for Jennison-Wright Isolates Based on } \\
{ }^{14} \mathrm{CO}_{2} \text { Production from Four Radiolabeled PAHs }\end{array}$} \\
\hline$\hat{\text { Microorganism }}$ & PAH Tested & $\frac{\text { Mineralization Rate, } \mu \mathrm{g} \text { CO, Produced } / \mathrm{ml} / \mathrm{hr}}{\text { (Mean } \pm \text { Standard Error) }}$ \\
\hline JWI46 & $\begin{array}{l}\text { Pyrene } \\
\text { Fluoranthene }\end{array}$ & $\begin{array}{l}221 \pm 8.86 \\
133 \pm 10.2\end{array}$ \\
\hline JWI17 & $\begin{array}{l}\text { Phenanthrene } \\
\text { Fluorene }\end{array}$ & $\begin{aligned} 13,911 & \pm 1492 \\
45.8 & \pm 5.03\end{aligned}$ \\
\hline
\end{tabular}




\section{Appendix A Screening of Jennison-Wright Soil for Degradation of Priority PAHs}




\begin{tabular}{|c|c|c|c|c|c|}
\hline \multirow{2}{*}{$\begin{array}{l}\text { Microblal } \\
\text { Isolate or } \\
\text { Consortium } \\
\text { No. }\end{array}$} & \multicolumn{5}{|c|}{ Priority PAH' } \\
\hline & Acenaphthene & Fluorene & Phenanthrene & Fluoranthene & Pyrene \\
\hline 1 & + & - & - & - & - \\
\hline 2 & + & - & - & - & - \\
\hline 3 & + & - & - & - & - \\
\hline 4 & - & $\mathrm{P}$ & - & - & - \\
\hline 5 & + & - & - & $P$ & - \\
\hline 6 & + & $\mathrm{P}$ & $P$ & $\mathbf{P}$ & - \\
\hline 7 & + & - & - & - & - \\
\hline 8 & + & - & - & - & - \\
\hline 9 & + & + & $\mathrm{P}$ & - & - \\
\hline 10 & + & + & - & - & - \\
\hline 11 & + & - & - & - & - \\
\hline 12 & + & $P / Y$ & - & - & - \\
\hline 13 & + & - & - & - & - \\
\hline 14 & - & - & - & - & - \\
\hline 15 & + & - & - & - & - \\
\hline 16 & + & - & - & - & - \\
\hline 17 & + & $+N$ & + & - & - \\
\hline 18 & + & - & + & - & - \\
\hline 19 & + & $+N$ & + & - & - \\
\hline 20 & + & - & - & - & - \\
\hline 21 & + & $Y$ & + & - & - \\
\hline 22 & + & - & - & - & - \\
\hline 23 & + & - & - & - & - \\
\hline 24 & + & - & - & - & - \\
\hline 25 & + & $+N$ & + & - & - \\
\hline 26 & + & $+N$ & + & - & - \\
\hline & & & & (Sh & et 1 of 5 \\
\hline $\begin{array}{l}1 \text { Symbols: }+ \\
P=\text { partial de } \\
\text { brown pigmen }\end{array}$ & $\begin{array}{l}\text { strong clearing of } \\
\text { ng of PAH; } M=r \\
\text { roduced. }\end{array}$ & $\begin{array}{l}\text { AH around } \\
\text { derate clei }\end{array}$ & $\begin{array}{l}\text { lony; }=\text { no clea } \\
g \text { of } P A H ; Y=y \epsilon\end{array}$ & $\begin{array}{l}\text { g of PAH around } \\
\text { ow pigment prodi }\end{array}$ & $\begin{array}{l}\text { colony; } \\
\text { ced; B = }\end{array}$ \\
\hline
\end{tabular}




\section{Appendix A Screening of Jennison-Wright Soil for Degradation of Priority PAHs}




\begin{tabular}{|c|c|c|c|c|c|}
\hline \multicolumn{6}{|c|}{$\begin{array}{l}\text { Table A1 } \\
\text { Screening of Jennison-Wright Soll for Degradation of Priority } \\
\text { PAHs }\end{array}$} \\
\hline \multirow{2}{*}{$\begin{array}{l}\text { Microbial } \\
\text { Isolate or } \\
\text { Consortium } \\
\text { No. }\end{array}$} & \multicolumn{5}{|c|}{ Priority PAH' } \\
\hline & Acenaphthene & Fluorene & Phenanthrene & Fluoranthene & Pyrene \\
\hline 1 & + & - & - & - & - \\
\hline 2 & + & - & - & - & - \\
\hline 3 & + & - & - & - & - \\
\hline 4 & - & $P$ & - & - & - \\
\hline 5 & + & - & - & $P$ & - \\
\hline 6 & + & $\mathrm{P}$ & $\mathrm{P}$ & $\mathbf{P}$ & - \\
\hline 7 & + & - & - & - & - \\
\hline 8 & + & - & - & - & - \\
\hline 9 & + & + & $P$ & - & - \\
\hline 10 & + & + & - & - & - \\
\hline 11 & + & - & - & - & - \\
\hline 12 & + & $\mathrm{P} Y$ & - & - & - \\
\hline 13 & + & - & - & - & - \\
\hline 14 & - & - & - & - & - \\
\hline 15 & + & - & - & - & - \\
\hline 16 & + & - & - & - & - \\
\hline 17 & + & $+M$ & + & - & - \\
\hline 18 & + & - & + & - & - \\
\hline 19 & + & $+M$ & + & - & - \\
\hline 20 & + & - & - & - & - \\
\hline 21 & + & Y & + & - & - \\
\hline 22 & + & - & - & - & - \\
\hline 23 & + & - & - & - & - \\
\hline 24 & + & - & - & - & - \\
\hline 25 & + & $+N$ & + & - & - \\
\hline 26 & + & $+N$ & + & - & - \\
\hline \multicolumn{6}{|c|}{ (Sheet 1 of 5 ) } \\
\hline $\begin{array}{l}1 \text { Symbols: + } \\
P=\text { partial de } \\
\text { brown pigmen }\end{array}$ & $\begin{array}{l}\text { trong clearing of } \\
\text { g of PAH; } M=r \\
\text { oduced. }\end{array}$ & $\begin{array}{l}\text { AH around } \\
\text { derate cles }\end{array}$ & $\begin{array}{l}\text { lony; }-=\text { no clea } \\
g \text { of } P A H ; Y=y\end{array}$ & $\begin{array}{l}\text { g of PAH arounc } \\
\text { ow pigment prod }\end{array}$ & $\begin{array}{l}\text { colony; } \\
\text { ced; B = }\end{array}$ \\
\hline
\end{tabular}




\begin{tabular}{|c|c|c|c|c|c|}
\hline \multirow{2}{*}{$\begin{array}{l}\text { Microbial } \\
\text { Isolate or } \\
\text { Consortium } \\
\text { No. }\end{array}$} & \multicolumn{5}{|c|}{ Priority PAH } \\
\hline & Acenaphthene & Fluorene & Phenanthrene & Fluoranthene & Pyrene \\
\hline 27 & + & + & - & - & - \\
\hline 28 & + & - & - & - & - \\
\hline 29 & - & - & - & - & - \\
\hline 30 & + & - & - & - & - \\
\hline 31 & + & - & - & - & - \\
\hline 32 & + & - & - & - & - \\
\hline 33 & + & - & - & - & - \\
\hline 34 & + & - & - & $P$ & $P$ \\
\hline 35 & + & - & $+/ B$ & - & - \\
\hline 36 & + & - & $+/ B$ & - & - \\
\hline 37 & $P$ & - & $+/ B$ & - & - \\
\hline 38 & $P$ & - & $+/ B$ & - & - \\
\hline 39 & - & - & $+/ B$ & - & $\mathrm{P}$ \\
\hline 40 & - & - & $+/ B$ & $\mathrm{P}$ & - \\
\hline 41 & $P$ & - & + & - & - \\
\hline 42 & + & - & $+/ B$ & - & - \\
\hline 43 & - & $\mathrm{P}$ & $+/ B$ & $M$ & - \\
\hline 44 & - & $\mathrm{P}$ & $+/ B$ & $M$ & - \\
\hline 45 & $P$ & - & $+/ B$ & - & $P$ \\
\hline 46 & - & $\mathrm{P}$ & + & + & + \\
\hline 47 & - & - & $+/ B$ & - & - \\
\hline 48 & - & - & - & - & - \\
\hline 49 & - & - & $\mathrm{P} / \mathrm{B}$ & - & - \\
\hline 50 & $P$ & $\mathrm{P}$ & + & - & - \\
\hline 51 & $p$ & $P$ & - & - & - \\
\hline 52 & - & - & - & - & - \\
\hline 53 & - & - & $+/ B$ & - & - \\
\hline 54 & - & - & - & - & - \\
\hline 55 & - & - & $+/ B$ & - & - \\
\hline 56 & - & - & $+/ B$ & - & - \\
\hline
\end{tabular}




\begin{tabular}{|c|c|c|c|c|c|}
\hline \multirow{2}{*}{$\begin{array}{l}\text { Microbial } \\
\text { Isolate or } \\
\text { Consortium } \\
\text { No. }\end{array}$} & \multicolumn{5}{|c|}{ Priority PAH } \\
\hline & Acenaphthene & Fluorene & Phenanthrene & Fluoranthene & Pyrene \\
\hline 57 & - & - & + & - & \\
\hline 58 & + & - & $P$ & - & - \\
\hline 59 & - & - & - & - & - \\
\hline 60 & - & - & + & - & - \\
\hline 61 & - & - & - & - & - \\
\hline 62 & - & - & + & - & - \\
\hline 63 & - & - & + & - & - \\
\hline 64 & - & - & + & - & - \\
\hline 65 & - & - & + & - & - \\
\hline 66 & - & - & + & - & - \\
\hline 67 & - & - & + & - & - \\
\hline 68 & - & - & + & - & - \\
\hline 69 & - & - & + & - & - \\
\hline 70 & - & - & + & - & - \\
\hline 71 & - & - & + & - & - \\
\hline 72 & - & - & $P$ & - & - \\
\hline 73 & $P$ & - & + & - & - \\
\hline 74 & - & - & $+/ B$ & - & - \\
\hline 75 & - & - & + & - & - \\
\hline 76 & - & - & $P$ & - & - \\
\hline 77 & - & - & - & - & - \\
\hline 78 & - & - & $+/ B$ & - & - \\
\hline 79 & - & - & - & - & - \\
\hline 80 & - & - & - & - & - \\
\hline 81 & - & - & - & - & - \\
\hline 82 & - & - & $+/ B$ & - & - \\
\hline 83 & - & - & - & - & - \\
\hline 84 & - & - & $+/ B$ & - & - \\
\hline 85 & - & - & - & - & - \\
\hline 86 & - & - & $P$ & - & - \\
\hline
\end{tabular}




\begin{tabular}{|c|c|c|c|c|c|}
\hline \multirow{2}{*}{$\begin{array}{l}\text { Microblal } \\
\text { Isolate or } \\
\text { Consortium } \\
\text { No. }\end{array}$} & \multicolumn{5}{|c|}{ Piority PAH } \\
\hline & Aenaphthene & Fluorene & Phenanthrene & Fluoranthene & Pyrene \\
\hline 87 & - & - & - & - & - \\
\hline 88 & - & - & - & - & - \\
\hline 89 & + & Y & - & $P$ & $P$ \\
\hline 90 & + & Y & - & $P$ & - \\
\hline 91 & - & - & - & - & - \\
\hline 92 & - & $P$ & $P$ & - & - \\
\hline 93 & - & - & + & - & - \\
\hline 94 & + & - & - & - & - \\
\hline 95 & + & - & - & - & - \\
\hline 96 & - & - & - & - & - \\
\hline 97 & - & - & - & - & - \\
\hline 98 & + & - & $P$ & - & - \\
\hline 99 & - & - & - & - & - \\
\hline 100 & + & - & - & - & - \\
\hline 101 & $\mathrm{P}$ & - & - & - & - \\
\hline 102 & $P$ & - & + & - & - \\
\hline 103 & - & - & + & - & - \\
\hline 104 & + & - & + & - & - \\
\hline 105 & + & - & + & - & - \\
\hline 106 & - & - & $P$ & - & - \\
\hline 107 & + & $P$ & - & $M$ & - \\
\hline 108 & + & - & $P$ & - & - \\
\hline 109 & - & - & - & - & - \\
\hline 110 & - & - & - & - & - \\
\hline 111 & + & - & - & - & - \\
\hline 112 & + & - & - & - & - \\
\hline 113 & - & - & + & - & - \\
\hline 114 & - & $\mathrm{P}$ & $P$ & - & $P$ \\
\hline 115 & $P$ & - & - & - & $P$ \\
\hline 116 & $P$ & - & $P$ & $M$ & - \\
\hline & & & & & et 4 of 5 \\
\hline
\end{tabular}




\begin{tabular}{|l|l|l|l|l|l||}
\hline \multicolumn{6}{||}{ Table A1 (Concluded) } \\
\hline \hline $\begin{array}{l}\text { Microblal } \\
\text { Isolate or } \\
\begin{array}{l}\text { Consortium } \\
\text { No. }\end{array}\end{array}$ & \multicolumn{5}{|c|}{ Priority PAH } \\
\cline { 2 - 7 } & Aenaphthene & Fluorene & Phenanthrene & Fluoranthene & Pyrene \\
\hline \hline 117 & - & - & $P$ & $P$ & $P$ \\
\hline 118 & - & - & $P$ & - & - \\
\hline 119 & - & - & $P$ & - & - \\
\hline 120 & - & - & - & - & - \\
\hline 121 & - & - & $P$ & - & - \\
\hline 122 & - & - & $P$ & - & - \\
\hline \hline
\end{tabular}



Davis Highway, Suite 1204. Arlington, VA 22202-4302, and to the Office of Management and Budget. Paperwork Reduction Project (0704-0188), Washington, DC 20503.

\begin{tabular}{|l|l|c|}
\hline 1. AGENCY USE ONLY (Leave blank) & $\begin{array}{c}\text { 2. REPORT DATE } \\
\text { Sedtember } 1993\end{array}$ & $\begin{array}{c}\text { 3. REPORT TYPE AND DATES COVERED } \\
\text { Einal report }\end{array}$ \\
\hline
\end{tabular}

4. TITLE AND SUBTITLE

5. FUNDING NUMBERS

Rapid Development of Microbial Strains for Bioremediation of Military Soils

and Dredged Materials Contaminated with Polycyclic Aromatic Hydrocarbons

6. AUTHOR(S)

Douglas Gunnison, Mark E. Zappi, and John R. Marcev

7. PERFORMING ORGANIZATION NAME(S) AND ADDRESS(ES)

8. PERFORMING ORGANIZATION REPORT NUMBER

U.S. Army Engineer Waterways Experiment Station

Environmental Laboratory

3909 Halls Ferry Road, Vicksburg, MS 39180-6199;

Technical Report

AScI Corporation, East Clay Street, Vicksburg, MS 39180

9. SPONSORING / MONITORING AGENCY NAME(S) AND ADDRESS(ES)

EL-93-18

Discetionary Research Program

U.S. Army Engineer Waterways Experiment Station

3909 Halls Ferry Road, Vicksburg, MS 39180-6199

11. SUPPLEMENTARY NOTES

Available from National Technical Information Service, 5285 Port Royal Road, Springfield, VA 22161.

12a. DISTRIBUTION/AVAILABILITY STATEMENT

12b. DISTRIBUTION CODE

Approved for public release; distribution is unlimited.

13. ABSTRACT (Maximum 200 words)

A study was undertaken to rapidly obtain native microorganisms or consortia (groups of microorganisms acting together to remove a contaminant or groups of contaminants) with the ability to degrade polycyclic aromatic hydrocarbon compounds (PAHs) in soils and sediments subject to aerobic biological treatment. A screening test was developed to select those microorganisms active against the broadest spectrum of priority PAHs (those PAHs present in highest concentration). Particular emphasis was also placed on selecting those microorganisms able to degrade PAH compounds normally resistant to biological treatment (pyrene, for example). Selected microorganisms were further examined to determine requirements for organic nutrients in addition to specific $\mathrm{PAH}(\mathrm{s})$ and to assess their ability to mineralize representative priority PAHs. Based on the results of this work, a single microorganism was selected for use in a bioslurry testing. In this procedure, the selected microorganism was grown up in large quantity and added back to the soil of origin as part of a biotreatment process. When added to previously sterilized soil slurry, the selected microorganism demonstrated significant removal of two of the four priority PAHs and slight removal of the remaining compounds in a 4-week period. When this microorganism was used in a soil slurry in combination with the native soil microbial populations, the levels of all four priority PAHs decreased significantly in the 4-week treatment period. The selected microorganism in the sterile soil treatment removed

(Continued)

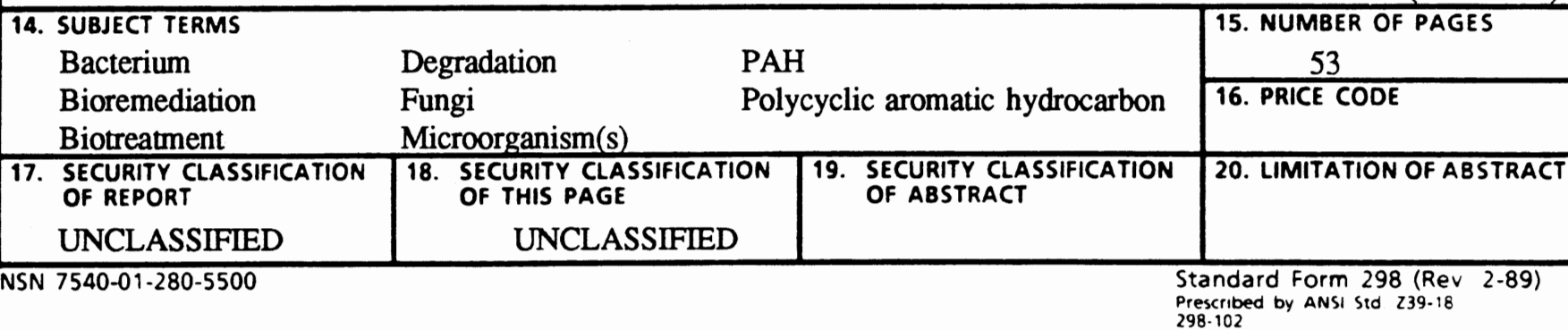




\section{3. (Concluded).}

64.5 percent of the total residual petroleum hydrocarbons (TRPHs). The selected microorganism and native microorganisms together were able to remove 78.5 percent of the TRPHs. Thus, use of native microorganisms improved TRPH removal only 13.9 percent over the level achieved with the selected microorganism alone.

The results of this work indicate that use of microorganisms selected for their ability to degrade PAHs from a native microbial population can enhance PAH degradation over use of native microorganisms only. 
